
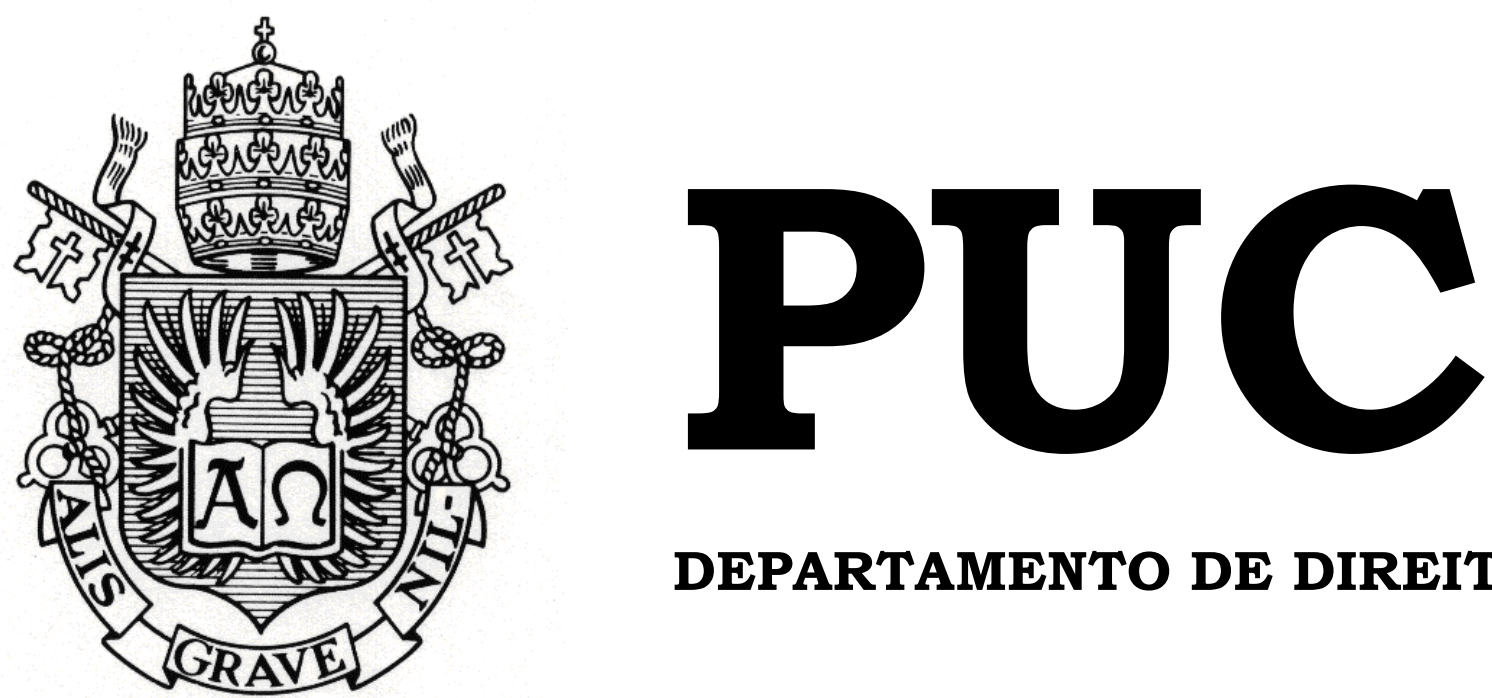

DEPARTAMENTO DE DIREITO

\title{
A ABSTRATIVIZAÇÃo DO CONTROLE DIFUSO À LUZ DA CONSTITUIÇÃO DA REPÚBLICA
}

por

JOSÉ LUÍs DA SILVA TAVARES

ORIENTADOR: Fábio Carvalho Leite

2012.1

PONTIFÍCIA UNIVERSIDADE CATÓLICA DO RIO DE JANEIRO

RUA MARQUÊS DE SÃO VICENTE, 225 - CEP 22453-900

RIO DE JANEIRO - BRASIL 


\title{
A ABSTRATIVIZAÇÃO DO CONTROLE DIFUSO À LUZ DA CONSTITUIÇÃO DA REPÚBLICA
}

\author{
por \\ JOSÉ LUÍS DA SILVA TAVARES
}

Monografia

apresentada

ao

Departamento de Direito da Pontificia Universidade Católica do Rio de Janeiro (PUC-Rio) para a obtenção do Título de Bacharel em Direito.

Orientador: Fábio Carvalho Leite 
Dedico o presente trabalho aо meи Tio, Revm ${ }^{o}$. Padre Ricardo Pereira Calvo, figura ilustre em minha vida. Sem ele, certamente, não teria alcançado essa vitória. 


\section{Agradecimentos}

A Deus, pelo dom da vida.

Aos meus pais, Maria Luiza e José Antônio.

Aos meus irmãos, Heloísa Cristina, Eliene Cristina, João Pedro e Paulo Henrique.

A minha namorada Amanda. Obrigado pela paciência e compreensão.

A todos os meus amigos. Obrigado pelos conselhos, sempre busquei ouvílos.

Ao meu Tio Pe. Ricardo Pereira Calvo, sem palavras para agradecê-lo por tudo que sempre fez e faz por mim.

Por fim, porém não menos importante, ao meu orientador Fábio Leite por todas as sábias orientações que sempre me foram muito úteis. 


\section{Resumo}

O presente trabalho monográfico tem por objetivo analisar criticamente a chamada teoria da 'abstrativização' do controle difuso de constitucionalidade à luz da Constituição da República Federativa do Brasil de 1988. O Supremo Tribunal Federal no julgamento da Reclamação 4.3355/AC, trouxe à tona interessante tese acerca dos efeitos da decisão no controle incidenter tantum, através dos votos dos ministros Gilmar Mendes, relator, e Eros Grau, segundo a qual os efeitos da declaração de inconstitucionalidade não se restringiriam somente às partes do processo, mas teriam eficácia erga omnes e efeito vinculante, dispensando-se a participação do Senado Federal prevista no artigo 52, X, da CF/88. A dispensa do Senado é justificada com base na teoria da mutação constitucional do referido dispositivo legal, o qual, na visão dos ministros, seria anacrônico. Acontece que essa tese, apesar de sedutora em um primeiro momento, na verdade, põe em risco a ordem constitucional, pois ofende diretamente o art.52, X, além de ser um perigoso precedente no que diz respeito à interpretação do texto constitucional, tendo em vista que a mutação, da forma como defendida pelos ministros, pode levar o Supremo Tribunal Federal a produzir (novos) textos e, por conseguinte, transformarse num poder constituinte permanente.

Palavras-chave: Controle de constitucionalidade; Supremo Tribunal Federal; Sistema misto; Controle concreto-difuso; Efeitos inter partes; Senado Federal; Freios e Contrapesos; Hermenêutica constitucional; Sentidos mínimos. 


\section{SUMÁRIO}

Introdução .......................................................................6

Capítulo 1 - O controle de constitucionalidade por via incidental no Supremo Tribunal Federal .....................................................8

1.1 Breve histórico do sistema de controle da constitucionalidade no

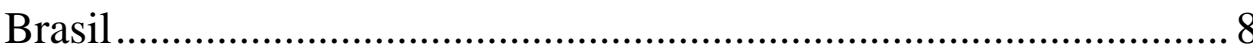

1.2 Princípio da reserva de plenário ou do full bench ........................ 17

1.3 Efeitos da decisão de inconstitucionalidade no caso concreto e a participação do Senado Federal ........................................................ 21

Capítulo - 2 A mutação constitucional do artigo 52, X, da CF/88 suscitada na Reclamação 4.335 ..................................................29

2.1 Reclamação 4.335-5/AC: análise dos votos ................................. 29

2.2 Senado Federal como diário oficial das decisões proferidas pelo STF no controle difuso: uma nova atribuição.

2.3 Fim do sistema misto (?): a equiparação dos efeitos da decisão nos controles concreto-difuso e abstrato-concentrado. 46

Capítulo 3 - Hermenêutica constitucional e os sentidos mínimos do texto legal:

3.1 Mutação constitucional: a substituição de um texto por outro texto? 53

3.2 Cabe ao Supremo Tribunal Federal corrigir a Constituição da República? 59

3.3 A tese da mutação como perigoso precedente: 61

Conclusão .66

Bibliografia 70 


\section{Introdução}

O presente trabalho tem por escopo analisar criticamente a chamada teoria da abstrativização do controle difuso à luz da atual Constituição da República brasileira. Alguns Ministros do Supremo Tribunal Federal, ao proferirem seus votos na Reclamação 4.335-5/AC, sustentaram que qualquer decisão da Corte no controle de constitucionalidade concretodifuso teria efeitos vinculantes e eficácia erga omnes. Essa tese trará sérias consequências para o sistema pátrio de controle da constitucionalidade se acaso for majoritária e vier a se concretizar.

No primeiro capítulo será abordado como o controle difuso se desenvolve perante o STF, com ênfase na sua competência recursal. É no Recurso Extraordinário que a Corte realiza com maior frequência o controle de constitucionalidade incidental de leis e atos normativos. Para caracterizar essa espécie recursal abordaremos, primeiramente, a inovação trazida pela Emenda Constitucional $\mathrm{n}^{\circ} 45$ de 2004, que acrescentou um novo requisito de admissibilidade a ser demonstrado pelo recorrente, qual seja a repercussão geral. Também veremos como a legislação ordinária tratou o tema, já que o texto constitucional (art. 102, $\S 3^{\circ}$ ) determinou que a repercussão geral fosse regulada na forma da lei. Outra característica do controle difuso que será destacada ao longo do capítulo é a cláusula de reserva de plenário, presente na Constituição (art. 97), que determina que qualquer Tribunal somente declare a inconstitucionalidade de lei ou ato normativo do poder público mediante o voto da maioria absoluta dos seus membros ou dos membros do respectivo órgão especial. Finalmente, veremos quais os efeitos da decisão de inconstitucionalidade proferida no caso concreto e abordaremos, ainda, todas as questões que envolvem a participação do Senado Federal nesse processo de controle da constitucionalidade. 
O segundo capítulo destina-se a aprofundar o tema acerca da abstrativização do controle difuso, o que faremos através do estudo da Reclamação Constitucional 4.335-5/AC. Essa reclamação foi ajuizada no STF no ano de 2006 e foi a partir dela que os Ministros Gilmar Mendes e Eros Roberto Grau sustentaram a tese de que a participação do Senado Federal no processo de controle da constitucionalidade, prevista no artigo 52, $\mathrm{X}, \mathrm{CR} / 88$, tornou-se um anacronismo. Com isso, os citados ministros passaram a defender a desnecessidade daquela casa legislativa em editar resolução suspendendo a execução da lei declarada inconstitucional. Para Gilmar Mendes e Eros Grau a decisão de inconstitucionalidade, proferida no caso concreto, já possuiria efeitos vinculantes contra todos, pois conteria força normativa suficiente para provocar a suspensão do diploma legal. Fundamentaram as suas teses com base na suposta mutação constitucional sofrida pelo artigo 52, X, CR/88. Ainda nesse capítulo, faremos uma crítica negativa a essa tese, pois o texto constitucional é claro ao prever a participação do Senado Federal no controle difuso, somente admitindo a eficácia erga omnes e os efeitos vinculantes para as decisões da Corte proferidas no controle abstrato-concentrado (art. 102, § $2^{\circ}, \mathrm{CR} / 88$ ) ou na hipótese de edição da súmula vinculante (art. 103-A).

Finalmente, no último capítulo, faremos uma abordagem mais teórica, em outras palavras, no campo da interpretação constitucional, pois a tese da mutação está intimamente ligada com a atividade interpretativa. Veremos os limites a serem enfrentados pelo intérprete do direito no exercício da sua atividade, e como o Ministro Eros Roberto Grau, ao propor um novo texto normativo para o artigo $52, \mathrm{X}$ da $\mathrm{CR} / 88$, se distanciou do contexto constitucional em que se encontra inserida essa norma. 


\section{Capítulo 1}

\section{O controle de constitucionalidade por via incidental no Supremo Tribunal Federal}

\subsection{Breve histórico do sistema de controle da constitucionalidade no}

Brasil:

O controle da constitucionalidade no Brasil possui uma característica peculiar que o difere de todos os outros no direito comparado, qual seja, ele é misto (ou híbrido). Consegue misturar tanto elementos do controle difuso quanto do controle concentrado onde um não se sobrepõe ao outro e viceversa.

A origem do controle difuso, como é por todos conhecida, foi no direito norte-americano, através do famoso caso Marbury vs. Madison, no qual a Suprema Corte entendeu que toda lei incompatível com a Constituição americana seria nula, cabendo ao Judiciário, como intérprete final daquela, exercer o controle de constitucionalidade das leis.

Esse modelo americano influenciou no nascimento do controle difuso de constitucionalidade do Brasil, que teve seu marco inicial na Constituição Federal de 1891, sendo mais tarde reforçado com o advento da Lei Federal $n^{\circ} 221$ de 20 de novembro de 1894, que organizou a Justiça Federal.

Porém, foi com a Constituição de 1934 que o controle difuso ganhou maiores contornos, pois aquele texto constitucional inovou ao trazer em seu bojo a cláusula da reserva de plenário e, ao mesmo tempo, a competência do Senado Federal para suspender a execução de lei declarada inconstitucional pelo Poder Judiciário, além de ter instituído a Representação Interventiva para solucionar conflitos federativos. 
A Constituição de 1937, apesar de autoritária, manteve o modelo de controle concreto-difuso inaugurado na Constituição de 1891, reproduzindo apenas uma das inovações presentes na Carta de 34, que foi a exigência do princípio da reserva de plenário, não cuidando da Representação Interventiva, tampouco da participação do Senado Federal no processo de suspensão da eficácia da lei declarada inconstitucional no caso concreto.

Findo o autoritarismo, surge a Constituição de 1946 que preservou o modelo de constitucionalidade difuso, recuperando, ainda, as supressões feitas pela Carta Política de 37.

Ainda na vigência da Constituição da República de 1946, mas já sob o domínio do regime militar, surge a Emenda Constitucional no 16/1965 que institui no controle de constitucionalidade brasileiro a então denominada ação genérica de inconstitucionalidade. Passava o Supremo Tribunal Federal a ter competência para declarar a inconstitucionalidade de lei ou ato federal, mediante representação que lhe fosse encaminhada pelo Procurador Geral da República. Introduzia-se, assim, no direito brasileiro um controle por via principal, mediante ação direta, em fiscalização abstrata e concentrada no STF.

O controle incidental e difuso, por sua vez, não foi afetado pela inovação trazida pela EC $\mathrm{n}^{\circ} 16 / 65$, passando a conviver com o denominado controle abstrato e concentrado.

O texto de 1967 não trouxe modificações importantes ao sistema de controle de constitucionalidade, tendo apenas suprimido a possibilidade da ação genérica no âmbito estadual, contida na EC nº 16/65. A Constituição de 1969, por sua vez, previu a ação direta em âmbito estadual, mas limitada à hipótese de intervenção do Estado em Município.

A atual Carta Política manteve o sistema misto, trazendo, todavia, um conjunto relativamente amplo de inovações, dentre as quais podem ser destacadas: a) a ampliação do rol de legitimados para propositura de ação 
direta (art. 103, CF/88); b) a introdução de mais 3 (três) importantes ações, a saber: ação direta de inconstitucionalidade por omissão (ADO), ação declaratória de constitucionalidade (ADC) e a arguição de descumprimento de preceito fundamental $(\mathrm{ADPF})$; c) a recriação da ação direta de inconstitucionalidade em âmbito estadual, denominada de representação de inconstitucionalidade (art. 125, $\S 2^{\circ}, \mathrm{CF} / 88$ ); e, por fim, d) a limitação do recurso extraordinário às questões constitucionais (art. 102, III, CF/88).

Acerca do controle difuso, mantido pela ordem constitucional de 1988, cabe destacar as palavras do Professor Barroso:

\footnotetext{
"O controle incidental difuso continuou a ser previsto de forma expressa, porém oblíqua, na disciplina do cabimento do recurso extraordinário, da qual decorre a inequívoca possibilidade de declaração de inconstitucionalidade por juízes e tribunais" (Barroso, 2012, p. 88).
}

No que diz respeito ao controle de constitucionalidade incidenter tantum, exercido, no caso concreto, perante o Supremo Tribunal Federal, este poderá realizá-lo tanto em processos de sua competência originária (art. 102, I, CF/88) quanto nos de sua competência recursal (art.102, II e III, $\mathrm{CF} / 88$ ) - recursos ordinário e extraordinário.

Todavia, é em sede de recurso extraordinário que o STF exerce frequentemente a fiscalização incidental de constitucionalidade de leis e atos normativos, como pressuposto lógico e necessário para a solução do mérito da causa.

Sendo através de recurso extraordinário que a Corte Suprema exerce com maior grau de frequência o controle de constitucionalidade, cabe, então, traçar algumas características desse recurso.

Segundo o disposto no artigo 102, III, da Constituição Federal, das causas decididas em única ou última instância, caberá recurso extraordinário quando a decisão recorrida: a) contrariar dispositivo desta Constituição; b) declarar a inconstitucionalidade de tratado ou lei federal; c) 
julgar válida lei ou ato de governo local contestado em face desta Constituição; d) julgar válida lei local contestada em face de lei federal.

A expressão "causas decididas" constante do caput do artigo 102 da CF pode levar a crer que apenas as decisões finais de mérito são passíveis de questionamento pela via do recurso extraordinário. Porém, conforme ressalta o professor Luis Roberto Barroso, “(...) o mecanismo presta-se à impugnação de qualquer decisão judicial definitiva - não sujeita a outro recurso - ainda que terminativa ou interlocutória" (Barroso, 2012, p. 130).

O RE não funciona como instrumento a ser utilizado pelo recorrente com o objetivo de ver reapreciadas as questões de fato e/ou reexame das provas, pois se assim o fosse, a Suprema Corte funcionaria como "terceiro grau" de jurisdição, e esse não foi o intuito do legislador constituinte originário.

Nesse sentido, cabe destacar a súmula 279 do STF: "Para simples reexame de prova não cabe recurso extraordinário".

Por conseguinte, admite-se em sede de recurso extraordinário a reapreciação, tão-somente, de matéria constitucional que tenha sido objeto de prequestionamento, ou seja, a questão deve ter sido enfrentada e decidida na instância ad quem, sob pena de não conhecimento do recurso.

Entendimento este já consolidado na súmula 282 do STF, segundo a qual: "É inadmissível o recurso extraordinário, quando não ventilada, na decisão recorrida, a questão federal suscitada".

Outro ponto de relevância e que merece especial atenção é a novidade trazida pela Emenda Constitucional n ${ }^{\circ}$ 45/2004 (Reforma do Poder Judiciário), que introduziu o parágrafo $3^{\circ}$ no artigo 102 da Constituição da República, determinando um novo requisito de admissibilidade, qual seja, a necessidade de demonstração de repercussão geral da questão constitucional por parte do recorrente. 
A repercussão geral é mais um instrumento que objetiva restringir o acesso à Corte Constitucional, o que não implica negar jurisdição aos interessados (art. $5^{\circ}, \mathrm{XXXV}, \mathrm{CRFB} / 88$ ), todavia, traduz-se como um verdadeiro filtro das demandas constitucionais, que, muitas das vezes, são meramente protelatórias.

Cabe, neste ponto, trazer à tona os comentários tecidos por Luis Roberto Barroso acerca do tema:

\begin{abstract}
"No direito comparado observar-se forte tendência de restringir a atuação das cortes constitucionais a número reduzido de causas de relevância transcendente. Uma das formas mais comuns para atingir esse propósito é permitir que exerçam algum grau de controle sobre as causas que irão apreciar. A principal justificativa para tal discricionariedade é promover a concentração de esforços nos temas fundamentais, (...)" (Barroso, 2012, p. 135-136).
\end{abstract}

Portanto, a intenção do legislador constituinte derivado ao criar esse novo instrumento foi não apenas reduzir o número de demandas perante a corte, mas também, fazer com que haja uma concentração maior de esforços nas causas mais relevantes, naquelas em que os interesses transcendam aos das partes, afetando, assim, um grande número de pessoas.

A redação do artigo $102, \S 3^{\circ}$, dispõe que a repercussão geral seja regulamentada na forma da lei, tendo o legislador ordinário, obedecendo ao comando constitucional, editado a Lei $\mathrm{n}^{\circ} 11.418$ em 19 de dezembro de 2006, que inseriu dois novos dispositivos no Código de Processo Civil CPC (arts. 543-A e 543-B) sobre o tema.

$\mathrm{O}$ artigo 543-A do CPC dispõe que o STF não conhecerá do RE quando a questão constitucional não oferecer repercussão geral, estabelecendo, ainda, no parágrafo primeiro, que o recorrente deverá demonstrar tal requisito em preliminar do recurso, para apreciação exclusiva da Excelsa Corte.

A definição de repercussão geral veio no parágrafo segundo do art. 543-A, não se adotando um conceito jurídico determinado para a sua caracterização, permitindo-se, assim, que o próprio STF venha, caso a caso, 
a definir o que seja uma questão relevante do ponto de vista econômico, político, social ou jurídico, que transcenda os interesses subjetivos das partes.

Somente é dispensada a demonstração de repercussão geral nas hipóteses em que o recurso impugnar decisão contrária a súmula vinculante ou jurisprudência dominante do Supremo Tribunal, situações em que a repercussão geral será presumida.

O juízo de admissibilidade acerca da existência ou não da repercussão geral será de competência da Turma, bastando o voto de quatro ministros para que se conclua o juízo positivo de admissibilidade, sem necessidade de remeter a questão ao Plenário.

Somente admite-se o juízo negativo de admissibilidade pela manifestação de dois terços dos membros Tribunal, ou seja, no mínimo oito votos, hipótese em que a questão sempre deverá ser levada ao pleno da corte, conforme determina o art. $103, \S 3^{\circ}$, in fine, da CF.

Negada a existência de repercussão geral no recurso extraordinário, o mesmo será inadmitido ( $\S 3^{\circ}$ do art. 102, CF) e a decisão valerá para todos os recursos que versem sobre matéria idêntica, os quais serão indeferidos liminarmente, salvo a possibilidade de revisão da tese, segundo procedimento a ser definido pelo Regimento Interno do STF.

$\mathrm{Na}$ análise da repercussão geral, poderá o relator, mediante decisão irrecorrível, admitir de ofício ou a requerimento, em prazo por ele fixado, a manifestação de terceiros, subscrita por procurador habilitado, sobre a questão da repercussão geral (art. $323, \S 3^{\circ}$ do RISTF).

Tal possibilidade demonstra a intenção de um debate democrático e aberto acerca de questões fundamentais, podendo-se fazer referência, neste ponto, à figura do amicus curiae, que é típica do controle por via de ação direta - art. $7^{\circ}$, $\S 2^{\circ}$ da Lei 9.868/99. 
A Lei 11.418/06 também introduziu ao Código de Processo Civil o artigo 543-B, o qual traz em seu bojo interessante mecanismo a fim de otimizar o trabalho da Corte, evitando a multiplicação de julgamentos idênticos, e, de certa forma, aproximando os controles de constitucionalidade difuso e concentrado.

O parágrafo primeiro do art. 543-B determina aos Tribunais de origem que encaminhem ao Supremo Tribunal Federal um ou mais recursos representativos da controvérsia, retendo os demais, cujos fundamentos sejam idênticos àqueles, até ulterior pronunciamento definitivo da Corte.

O processamento da análise da repercussão geral nessas hipóteses multiplicidade de recursos com fundamento na mesma controvérsia - foi disciplinado pelo Regimento Interno do STF nos artigos 322 a 328.

O artigo 328 do RISTF regula situação na qual o Presidente do Tribunal ou Relator fará comunicação às instâncias de origem sobre possível multiplicidade de recursos:

\begin{abstract}
"Protocolado ou distribuído recurso cuja questão for suscetível de reproduzir-se em múltiplos feitos, a Presidência do Tribunal ou o (a) Relator (a), de ofício ou a requerimento da parte interessada, comunicará o fato aos tribunais ou turmas de juizado especial, a fim de que observem o disposto no art. 543-B do Código de Processo Civil, podendo pedir-lhes informações, que deverão ser prestadas em cinco dias, e sobrestar todas as demais causas com questão idêntica".
\end{abstract}

Proferida a decisão sobre a repercussão geral, surgem duas possibilidades: a) se o STF decidir pela inexistência da repercussão geral, consideram-se não admitidos os recursos extraordinários e eventuais agravos interpostos na instância ad quem (art. 543-B, § 2, $\mathrm{CPC}$ c/c art. 328-A, $\$ 1^{\circ}$ do RISTF); b) se o STF decidir pela existência da repercussão geral, deve-se aguardar a decisão sobre o mérito dos recursos representativos.

Caso o STF adentre o mérito da causa e profira decisão, os recursos sobrestados deverão ser analisados pelos Tribunais, Turmas de Uniformização ou Turmas Recursais, conforme o caso, que poderão: a) 
declará-los prejudicados, caso a decisão recorrida encontre-se em conformidade com o que foi decidido; ou b) se retratar, quando o acórdão estiver em desconformidade com a decisão da corte.

$\mathrm{Na}$ hipótese de manutenção da decisão, em desacordo com a orientação firmada no recurso representativo, o STF poderá cassá-la ou reformá-la, liminarmente, na forma do $\S 4^{\circ}$ do artigo 543-B do CPC. O RISTF em seu artigo $328, \S 2^{\circ}$ estabelece que: "julgado o mérito do recurso extraordinário em sentido contrário ao dos acórdãos recorridos, o Tribunal de origem remeterá ao Supremo Tribunal Federal os agravos em que não se retratar".

De acordo com essa dinâmica estabelecida pelo legislador, através da introdução da repercussão geral e dos recursos representativos no ordenamento jurídico pátrio, é perceptível sua vontade de vincular as instâncias inferiores às decisões do Supremo Tribunal, porém conforme ressalva Barroso: “(...) vinculação fundada em imperativo de racionalidade e isonomia, sem prejuízo de se admitirem exceções diante de motivos relevantes, devidamente demonstrados (...)" (Barroso, 2012, p. 146).

Portanto, correta, de certa maneira, a percepção de que, atualmente, o controle difuso e o controle concentrado de constitucionalidade estão mais próximos, principalmente após o advento da Lei 11.418/06, que regula o $\S$ $3^{\circ}$ do art. 102 da $\mathrm{CF}$, posto que aquela legislação caminhou no sentido de valorizar a decisão do STF (paradigma), seja em relação à existência de repercussão geral, seja em relação ao mérito dos recursos representativos.

Veja-se, a título ilustrativo, que quando o STF adentra no mérito do recurso representativo, e entende que determinada lei ou ato normativo é inconstitucional, essa decisão deverá ser observada pelos Tribunais, e aqueles que já tinham adotado posição de acordo com a corte, deverão julgar prejudicados os recursos que foram interpostos e estavam sobrestados 
até então, enquanto os que tinham proferido decisão contrária ao entendimento que foi firmado, poderão emitir juízo de retratação.

Destarte, é possível falar-se em um suposto efeito vinculante daquele precedente, pois ainda que o tribunal ad quem possa manter a sua decisão em desconformidade com orientação firmada, a legislação processual civil prevê que o órgão de cúpula poderá, em sede de recurso extraordinário, cassar ou reformar o acórdão recorrido, com base no artigo $543-\mathrm{B}, \S 4^{\mathrm{o}}$, in verbis: "mantida a decisão e admitido o recurso, poderá o Supremo Tribunal Federal, nos termos do Regimento Interno, cassar ou reformar, liminarmente, o acórdão contrário à orientação firmada”.

Todavia, não se trata de uma vinculação de fato, pois o Tribunal poderá recusar-se a fazer juízo de retratação e, desta forma, manter o seu entendimento, ainda que posteriormente venha o acórdão a ser cassado ou reformado pelo Supremo Tribunal em sede de recurso extraordinário.

Não é outro o entendimento da Corte Constitucional:

“(...) 2. Cabe aos juízes e desembargadores respeitar a autoridade da decisão do Supremo Tribunal Federal tomada em sede de repercussão geral, assegurando racionalidade e eficiência ao Sistema Judiciário e concretizando a certeza jurídica sobre o tema. 3. O legislador não atribuiu ao Supremo Tribunal federal o ônus de fazer aplicar diretamente a cada caso concreto o seu entendimento. 4. A lei n. $11.418 / 2006$ evita que o Supremo Tribunal Federal seja sobrecarregado por recursos extraordinários fundados em idêntica controvérsia, pois atribuiu aos demais Tribunais a obrigação de os sobrestarem e a possibilidade de realizarem juízo de retratação para adequarem seu acórdão à orientação de mérito firmada por esta corte. 5. Apenas na rara hipótese de que algum Tribunal mantenha posição contrária à do Supremo Tribunal Federal, é que caberá a este se pronunciar, em sede de recurso extraordinário, sobre o caso particular idêntico para a cassação ou reforma do acórdão, nos termos do art. 543-B, $\S 4^{\circ}$, do Código de Processo Civil (...) 9. Nada autoriza ou aconselha que se substituam as vias recursais ordinárias e extraordinárias pela reclamação (...) 10. A novidade processual que corresponde à repercussão geral e seus efeitos não deve desfavorecer as partes, nem permitir a perpetuação de decisão frontalmente contrária ao entendimento vinculante adotado pelo Supremo Tribunal Federal. Nesses casos o questionamento deve ser remetido ao Tribunal competente para a revisão das decisões do Juízo de primeiro grau a fim de que aquela Corte o aprecie como recurso cabível, independentemente de considerações sobre sua tempestividade (...)" (STF, DJe, 3 de jul. 2011, Rcl. 10793-SP, rel. ${ }^{a}$ Min. $^{a}$ Ellen Gracie) (grifo nosso). 
Por fim, não se tratando de recurso extraordinário suscetível de gerar multiplicidade de processos com idêntica controvérsia constitucional, não há que se falar no procedimento previsto pela lei 11.418/2006, devendo o STF, na declaração incidental de inconstitucionalidade, fazer a comunicação ao Senado Federal para que esta casa legislativa, querendo, edite resolução suspendendo a execução, no todo ou em parte, do diploma legal declarado inconstitucional por decisão definitiva (art. 52, X do STF; art. 178 do RISTF).

\subsection{Princípio da reserva de plenário ou do full bench:}

A Constituição da República de 1934 introduziu importantes alterações no controle de constitucionalidade brasileiro, a saber: a) estabeleceu na forma do art. 179 o princípio da reserva de plenário, determinando que a decisão de inconstitucionalidade, de lei ou ato do poder público, proferida pelos Tribunais, só seria válida se declarada por decisão da maioria absoluta de seus membros; b) atribuiu ao Senado Federal, arts. 91, IV e 96, a competência para suspender a execução de lei declarada inconstitucional pelo Poder Judiciário; c) e, por fim, instituiu a Representação Interventiva, privativa do Procurador Geral da República e sujeita à competência originária do STF, na forma do art. $12, \S 2^{\circ}$.

Das inovações acima mencionadas, aquela que interessa é a que diz respeito à cláusula da reserva de plenário, instituto presente no controle de constitucionalidade brasileiro desde 1934 e ratificado pela atual Carta Política.

O artigo 97 da CRFB dispõe que somente pelo voto da maioria absoluta dos membros do Tribunal ou dos membros do respectivo órgão especial é que se poderá declarar a inconstitucionalidade de uma lei ou ato normativo, dando-se, assim, maior legitimidade àquela decisão, pois se trata de um quorum qualificado que exige mais da metade dos votos no mesmo sentido. 
Este dispositivo atende ao princípio da presunção de constitucionalidade da qual goza toda lei emanada do poder legislativo, portanto é necessário que o suposto vício salte aos olhos de um grande número de julgadores experientes para que seja declarada sua inconstitucionalidade.

A reserva de plenário é disciplinada pelo Código de Processo Civil nos artigos 480 a 482 . Todavia, é a redação do parágrafo único do art. 481 que mais interessa ao presente trabalho, pois esta norma estabelece que os órgãos fracionários dos tribunais não submeterão ao plenário, ou ao órgão especial, a arguição de inconstitucionalidade, quando já houver pronunciamento destes ou do plenário do STF.

A redação do parágrafo único do art. 481 do CPC pode levar a interpretações diversas, havendo, de um lado, aqueles que defendem que a norma trata de uma vinculação do órgão fracionário às decisões proferidas pelo Supremo Tribunal (controle concreto-difuso) e, do outro lado, os que entendem que não há vinculação, mas tão-somente uma dispensa de remessa da questão, podendo o órgão fracionário decidir pela constitucionalidade ou inconstitucionalidade do ato questionado, sendo que naquela hipótese estará amparado pela presunção de constitucionalidade da lei e, nesta hipótese, pela jurisprudência do Pleno do Tribunal/Órgão Especial ou do STF.

Arguida a inconstitucionalidade, por qualquer das partes, pelo Ministério Público, pelo relator ou por um de seus pares, o relator submeterá a questão ao órgão fracionário para que decida sobre a procedência ou não do incidente. Se a arguição for rejeitada, o processo seguirá seu trâmite normal, inclusive sendo aplicada a norma antes questionada, pois ratificada a sua compatibilidade com a Lei Maior.Por outro lado, caso o órgão fracionário entenda pela inconstitucionalidade da lei ou do ato normativo, não poderá seguir com o julgamento do processo, devendo remeter a questão prejudicial ao pleno ou órgão especial do 
Tribunal, que deliberará a respeito, observado o quorum de maioria absoluta para poder declarar a inconstitucionalidade.

Todavia, o órgão fracionário estará dispensado de submeter a questão ao pleno ou ao órgão especial quando já houver pronunciamento destes ou do plenário do STF, podendo adentrar no mérito da questão sem necessidade de observância da cláusula de reserva de plenário.

Essa dispensa de remessa ao pleno poderá decorrer de duas situações distintas: a) quando o órgão fracionário decidir pela constitucionalidade do ato; b) ou quando acolher a arguição de inconstitucionalidade tendo por amparo uma decisão do plenário do STF ou do plenário do Tribunal ao qual está vinculado, com base no parágrafo único do art. 481 do CPC.

Cabe destacar que alguns Tribunais de Justiça, ao regularem a matéria em seus regimentos, determinam que os órgãos fracionários sigam o entendimento firmado pelo órgão especial, seja ele pela constitucionalidade ou inconstitucionalidade, vinculando-os, desta maneira, ao que for decidido. Porém, conforme destaca o Professor Fábio Leite em seu artigo sobre o tema, não cabe falar em uma vinculação definitiva, pois os próprios regimentos estabelecem de forma expressa a possibilidade de os órgãos fracionários provocarem novamente o órgão especial, desde que presente um motivo relevante que possa levá-lo a rever o entendimento anteriormente firmado.

Outro aspecto interessante acerca do tema é quando houver decisões conflitantes do STF e do pleno do Tribunal, esclarecendo o Professor Fábio Leite, no mesmo estudo sobre a matéria, que a melhor interpretação do dispositivo processual é aquela que atribui liberdade ao órgão fracionário, podendo declarar a constitucionalidade do ato normativo, sempre que achar conveniente, como decorrência do princípio da presunção de constitucionalidade, ainda que haja decisão do Supremo Tribunal ou do órgão especial pela inconstitucionalidade. 
Assim, a decisão do órgão de cúpula, qualquer que seja, em sede de controle difuso de constitucionalidade, não vincula os demais órgãos fracionários, defender tal possibilidade seria restringir a liberdade de interpretar o texto constitucional, e, consequentemente, caminhar para uma concentração do controle de constitucionalidade, ideia esta contrária ao Estado Democrático de Direito, pois o sistema brasileiro de controle da constitucionalidade é misto, somente podendo falar-se em efeitos erga omnes e vinculantes no controle concentrado-abstrato ou por via de ação direta (ADIn, ADC e ADPF).

Portanto, a melhor interpretação acerca do dispositivo processual é aquela que defende que não há uma vinculação/restrição do órgão fracionário ao que foi decidido, mas sim uma liberação/dispensa da observância da cláusula de reserva de plenário, com base na jurisprudência do órgão especial ou do plenário da Corte Constitucional, mantendo-se, dessa forma, um diálogo aberto e pluralista acerca da questão constitucional.

Inclusive a jurisprudência do Supremo Tribunal Federal tem admitido essa dispensabilidade de encaminhamento ao Pleno da Corte das questões constitucionais, por parte de suas Turmas, quando já houver decisão a respeito do tema.

Mais uma vez não se trata de uma vinculação, mas tão-somente de uma orientação que poderá vir a ser adotada ou não, pois se assim não o fosse, estaríamos diante de um sistema de controle da constitucionalidade que se caracteriza por ser exclusivamente concentrado, onde qualquer decisão tem efeitos vinculantes contra todos. 


\subsection{Efeitos da decisão de inconstitucionalidade no caso concreto e a participação do Senado Federal:}

Como já destacado, o Supremo Tribunal Federal poderá declarar incidentalmente a inconstitucionalidade de uma lei, tanto nas causas de sua competência originária quanto nas de competência recursal.

Em qualquer dessas hipóteses, dentre as quais a mais corriqueira é a do RE, o Supremo Tribunal Federal, em decisão do pleno, por maioria absoluta, poderá declarar a inconstitucionalidade de uma lei, que, via de regra, produzirá efeitos inter partes e retroagirá para atingir a lei viciada desde a sua origem, tornando-a nula de pleno direito. Assim, no controle difuso, os efeitos serão: a) inter partes e b) ex tunc.

Contudo, o legislador constituinte, desde 1934, com exceção do Estado Novo, até os dias atuais, estabelece a competência do Senado Federal de, por meio de resolução, suspender a execução da lei declarada inconstitucional por decisão definitiva do Supremo Tribunal (art. 52, X, CRFB/88).

Desse modo, a outorga ao Senado Federal de competência para suspender a execução da lei inconstitucional teve por motivação atribuir eficácia geral à decisão proferida no caso concreto, cujos efeitos se irradiam, ordinariamente, apenas em relação às partes processuais.

Quando o STF declara a inconstitucionalidade incidental de uma lei ou ato normativo, ele tem o dever de comunicar ao Senado Federal, conforme prevê o seu Regimento Interno no art. 178, abrindo-lhe a oportunidade de executar a competência descrita no art. 52, X, da CF/88.

Todavia, não é apenas através da comunicação feita pelo Presidente do STF ao Senado que se dará o conhecimento da decisão proferida, prevendo o artigo 386 do Regimento Interno do Senado Federal outras hipóteses. 
Art. 386: O Senado conhecerá da declaração, proferida em decisão definitiva pelo Supremo Tribunal Federal, de inconstitucionalidade total ou parcial de lei mediante:

I) comunicação do Presidente do Tribunal;

II) representação do Procurador Geral da República;

III) projeto de resolução de iniciativa da Comissão de Constituição, Justiça e Cidadania.

Depreende-se assim, que poderá o próprio Senado Federal, ex officio, através de sua CCJ, deflagrar o processo legislativo de edição da resolução, cujo objeto será a suspensão da norma declarada inconstitucional, independentemente da comunicação do STF.

Acerca do papel desempenhado pelo Senado Federal diversas questões são enfrentadas pela doutrina e pela jurisprudência, que dizem respeito à atuação (discricionária ou vinculada), à extensão da suspensão da execução (total ou parcial), e, por fim, aos efeitos propriamente ditos (ex tunc ou ex nunc).

Em relação à atuação do Senado Federal no controle de constitucionalidade difuso, pode-se afirmar que tanto na doutrina quanto na jurisprudência o tema é pacífico e, em nome do Princípio da Separação dos Poderes, entende-se que a atuação do Senado não tem caráter vinculado, mas discricionário. Segundo ensina Pedro Lenza:

"Deve-se, pois, entender que o Senado Federal não está obrigado a suspender a execução de lei declarada inconstitucional por decisão definitiva do Supremo Tribunal Federal. Trata-se de discricionariedade política, tendo o Senado Federal total liberdade para cumprir o art. 52, X, da CF/88. Caso contrário, estaríamos diante de afronta ao princípio da separação de Poderes" (Lenza, 2010, p. 231).

O mesmo não se afirma quando o tema é a extensão da suspensão da execução da norma declarada inconstitucional, havendo, nesse sentido, divergência doutrinária.

Parte da doutrina (MERLIN CLÈVE, Clèmerson) defende que o Senado Federal pode escolher suspender apenas parte do que foi declarado inconstitucional pelo STF, sob o argumento da teoria dos poderes implícitos, pois quem pode o mais pode o menos. Logo, se cabe ao Senado 
optar por suspender ou não a norma (atividade discricionária), com mais razão poderá escolher, caso edite a resolução, a parte que pretende suspender da lei declarada inválida pelo Supremo Tribunal Federal.

A segunda corrente (AFONSO DA SILVA, José) defende a tese de que a expressão "no todo ou parte" constante da redação do art. 52, X, dever ser interpretada como sendo impossível ao Senado Federal ampliar, interpretar ou restringir a extensão da decisão do STF. Assim, deve esta casa legislativa, ao optar pela suspensão, ficar adstrita ao conteúdo do que foi declarado inconstitucional, não podendo ir além ou aquém. Nesse sentido as palavras da professora Flavia Bahia Martins:

\begin{abstract}
"A segunda corrente, da qual compartilhamos, sustenta que o Senado Federal pode, no máximo, escolher entre suspender ou não a norma declarada inconstitucional, porém, se decidir pela suspensão, está vinculado ao conteúdo do que foi declarado inconstitucional pelo STF. Não sendo assim, o SF estaria fazendo novo julgamento acerca da inconstitucionalidade já declarada e este poder não lhe foi atribuído pelo art. $52, \mathrm{X}$, da $\mathrm{CF} / 88$. A única interpretação possível para a expressão 'no todo ou em parte' é no sentido de que o STF pode fazer a declaração parcial ou total da inconstitucionalidade da lei ou ato normativo. Do contrário, o SF estaria usurpando função do STF, de acordo com o próprio entendimento da Corte" (Martins, 2011, p. 514).
\end{abstract}

Não é outro o posicionamento da jurisprudência pátria, acompanhado a segunda corrente, sobre a vinculação do Senado Federal à decisão proferida pela Corte:

Ação direta de inconstitucionalidade. Medida cautelar concedida. Referendo. Resolução 7, de 21-6-2007, do Senado Federal.Suspensão erga omnes da eficácia de todo o texto de leis relativas à cobranca do ICMS no Estado de São Paulo.Declaracão de inconstitucionalidade anteriormente estendida, no exercício do controle difuso, apenas aos dispositivos que haviam prorrogado a majoracão de alíquota e a sua vinculacão a uma finalidade específica. Plausibilidade jurídica da alegação de ofensa ao art. 52, X, da CF. Perigo na demora igualmente demonstrado. $\mathrm{O}$ ato normativo impugnado, ao conferir eficácia erga omnes a um julgado singular, revela sua feição geral e obrigatória, sendo, portanto, dotado de generalidade, abstração e impessoalidade. Precedentes. O exame minucioso das decisões plenárias proferidas nos autos dos RE 183.906, 188.443 e 213.739 demonstra que a declaração de inconstitucionalidade dos atos normativos que sucederam à Lei estadual paulista 6.556/1989 alcançaram, tão somente, os dispositivos que tratavam, exclusivamente, da majoração da alíquota do ICMS e sobre a vinculação desse acréscimo percentual ao fundo criado para o desenvolvimento de determinado programa habitacional. O Senado Federal, em grande parte orientado por comunicações provenientes da Suprema Corte, acabou por retirar do mundo jurídico dispositivos das Leis paulistas 7.003/1990 e 7.646/1991, que, embora formalmente abarcados pela proclamação da inconstitucionalidade do próprio Diploma em que inseridos, em nenhum 
momento tiveram sua compatibilidade com a $\mathrm{CF}$ efetivamente examinada por este Supremo Tribunal. Plausibilidade da tese de violação ao art. 52, X, da Carta Magna. Deferimento de medida cautelar referendado pelo Plenário."(ADI 3.929MC, Rel ${ }^{a}$. Min ${ }^{a}$. Ellen Gracie, julgamento em 29-8-2007, Plenário, DJ de 11-102007.) (grifo nosso)

Por fim, a parte mais polêmica e, consequentemente, a que gera maiores debates na doutrina e jurisprudência é quanto aos efeitos atribuídos à resolução do Senado que suspende a execução da lei declarada inconstitucional pelo STF, havendo aqueles que afirmam serem ex tunc, e outros que entendem pelos efeitos ex nunc.

Para a primeira corrente, os efeitos produzidos pela edição da resolução que suspende a lei declarada inconstitucional devem ser futuros, não alcançando as situações pretéritas que foram constituídas sob a égide daquele diploma legal. Portanto, a resolução só poderá produzir efeitos do momento de sua publicação em diante, consistindo a suspensão da execução da lei declarada inconstitucional numa verdadeira revogação.

Segundo os ensinamentos da professora Flavia Bahia:

\begin{abstract}
"Funda-se esta corrente no fato de que a suspensão da norma é uma faculdade atribuída do Senado Federal, não é uma obrigatoriedade. Portanto, se ele pode decidir não suspender, caso suspenda a decisão só valerá dali por diante. Esta corrente é a majoritária na doutrina, a qual também compartilhamos" (Martins, 2011, p. 513).
\end{abstract}

A corrente contrária entende que suspender a execução de uma lei é ir além da sua simples revogação, afirmando que esta opera apenas ex nunc, alcançando a lei ou o ato revogado só a partir da vigência do ato revogador, enquanto que a suspensão opera efeitos ex tunc, atingindo a lei viciada desde sua origem, pois aquilo que é inconstitucional é nulo.

Logo, para esta segunda corrente, a resolução do Senado Federal produz os mesmos efeitos temporais da decisão proferida no caso concreto, ou seja, retroage para proteger as situações praticadas com base na lei declarada inconstitucional. O ministro Gilmar Mendes, adepto desta corrente, em artigo de sua autoria aduz que: 
"O Senado Federal não revoga o ato declarado inconstitucional, até porque lhe falece competência para tanto. Cuida-se de ato político que empresta eficácia erga omnes à decisão do Supremo Tribunal proferida em caso concreto" (Mendes, 2004, p. 154).

Outro argumento utilizado pelos que adotam a teoria da nulidade é no sentido de que não se pode determinar efeitos diferentes para quem é parte e para quem não é, sob pena de se estar violando o princípio da igualdade entre as pessoas.

Esta corrente é minoritária, prevalecendo, dessa forma, o entendimento de que os efeitos produzidos pela resolução serão, via de regra, erga omnes e ex nunc.

Todavia, cabe destacar que o Decreto 2.346/97 em seu artigo $1^{\circ}, \S \S$ $1^{\circ}$ e $2^{\circ}$, estabelece expressamente que para a administração pública federal direta e indireta a resolução do Senado produzirá efeitos ex tunc, o que, de certa forma, legitima o posicionamento sustentado pela corrente minoritária.

Apesar de sedutora a ideia de efeitos prospectivos, entendemos que o mais coerente seria seguir a tese da nulidade, segundo a qual todo ato em desconformidade com a Constituição de um Estado deve ser declarado nulo pelo Poder Judiciário, protegendo-se, dessa forma, aqueles que foram prejudicados pela lei viciada, conforme leciona Barroso: "De fato, corolário da supremacia da Constituição é que uma norma inconstitucional não deva gerar direitos ou obrigações legitimamente exigíveis” (Barroso, 2012, p.151).

Portanto, quando a Casa Legislativa resolve, por um critério de conveniência e oportunidade, editar resolução suspendendo a execução de uma lei declarada inconstitucional pelo Supremo Tribunal, deverão seus efeitos retroagirem para também proteger as situações passadas. Isso significa que o Senado Federal está vinculado à decisão da corte em todos os sentidos, seja em relação ao conteúdo (inconstitucionalidade total ou parcial) seja em relação aos efeitos por ela produzidos. 
Todavia, nem sempre o reconhecimento da inconstitucionalidade no controle difuso produzirá efeitos retroativos, podendo, em alguns casos, a Suprema Corte modular os efeitos e determinar que a decisão seja observada a posteriori, isso em nome da segurança jurídica ou mesmo da impossibilidade fática de se desfazer o ato praticado sob a égide da lei maculada.

Antes mesmo da entrada em vigor da lei 9.868/99, que prevê a declaração de inconstitucionalidade sem a pronúncia de nulidade, a jurisprudência da corte já admitia a mitigação dos efeitos da declaração de inconstitucionalidade no controle difuso.

Com o advento da referida lei, a corte passou, então, a aplicar, por analogia, o artigo 27 aos casos concretos em que seria inviável atingir a lei desde a sua edição.

Portanto, somente em tais situações é que estaria a resolução do SF autorizada a produzir efeitos pro futuro, devendo também ser observado, pela casa legislativa, se for o caso, o marco estabelecido pelo Supremo Tribunal para o cumprimento da decisão.

Conforme já dito, a resolução do Senado Federal só teria poderes de emprestar à decisão do STF efeitos erga omnes, devendo, quanto à eficácia temporal, seguir o que foi determinado pela corte no caso concreto.

Pensar de outra forma seria ilógico e injusto. Basta imaginar o seguinte exemplo: sendo declarada a inconstitucionalidade incidental de uma lei estadual que instituiu determinado tributo e feita a comunicação ao Senado Federal, este resolve editar resolução suspendendo a execução da lei estadual. Supondo-se que os efeitos da decisão do STF foram retroativos apenas o contribuinte que bateu às portas do Judiciário seria beneficiado com o estorno da quantia paga durante o tempo que a lei era presumida constitucional, eis que a resolução produziria efeitos pro futuro com relação aos demais contribuintes. A partir disso, pergunta-se: por que somente um 
contribuinte deverá ser beneficiado? E quanto àqueles que também tiverem que pagar o mesmo tributo?Não fariam jus à devolução do valor pago indevidamente?

Contudo, caso a receita arrecadada com os tributos já tivesse sido convertida em renda a favor do Estado, deveria o STF deixar de dar efeitos retroativos à decisão de inconstitucionalidade e estabelecer um prazo para que o tributo não mais fosse cobrado, pois impossível seria fazer o estorno dos valores pagos indevidamente. Consequentemente, a resolução do SF também não teria efeitos retroativos, tão-somente pro futuro.

Para encerrar o assunto, cabe trazer à baila interessante comentário feito pelo professor Barroso ao tratar do papel do Senado Federal no controle difuso, para quem:

\footnotetext{
“(...) não parece razoável e lógica, com a vênia devida ao ilustres autores que professam entendimento diverso, a negativa de efeitos retroativos à decisão plenária do Supremo Tribunal Federal que reconheça a inconstitucionalidade de uma lei. Seria uma demasia, uma violação ao princípio da economia processual, obrigar um dos legitimados do art. 103 a propor ação direta para produzir uma decisão que já se sabe qual é!

Por evidente, o reconhecimento da inconstitucionalidade- seja em controle abstrato, seja pela extensão dos efeitos da decisão em concreto - não afeta, direta e automaticamente, todas as situações preexistentes. Em nome da segurança jurídica, da justiça e de outros valores constitucionais, haverá hipóteses protegidas pela coisa julgada, pela boa-fé, pela prescrição ou decadência ou outros bens e interesses que imponham ponderação, como já admitido pela jurisprudência do Supremo Tribunal Federal, mesmo antes das inovações legislativas que permitiram a declaração de inconstitucionalidade sem a pronúncia de nulidade" (Barroso, 2012, p. 157-158).
}

Porém, toda esta discussão acerca da atuação do Senado Federal no controle difuso é posta em dúvida a partir dos votos proferidos pelos Ministros Gilmar Mendes e Eros Grau na Reclamação 4.335, pois ambos passaram a sustentar que a participação daquela casa legislativa tornou-se desnecessária diante da atual conjuntura do ordenamento constitucional. Assim sendo, qualquer decisão do plenário da Corte acerca da constitucionalidade ou inconstitucionalidade, proferida no controle difuso, teria efeitos vinculantes e eficácia erga omnes. 
É esse o tema que passa a ser objeto do próximo capítulo. 


\section{Capítulo 2}

\section{A mutação constitucional do artigo $52, X$, da CF/88 suscitada na Reclamação 4.335}

\subsection{Reclamação 4.335-5/AC: análise dos votos}

A Reclamação 4.335-5/AC chegou ao Supremo Tribunal Federal em meados de agosto de 2006 sendo os Ministros Gilmar Mendes, Eros Grau, Sepúlveda Pertence e Joaquim Barbosa os únicos que até o presente momento proferiram seus votos. O julgamento foi interrompido após pedido de vista dos autos formulado pelo Ministro Ricardo Lewandowski em 19 de abril de 2007.

Em consulta ao site da Corte verifica-se que os autos foram devolvidos em 10 de fevereiro de 2011 e decorridos mais de um ano o processo ainda encontra-se pendente de julgamento, talvez porque a Corte Constitucional tenha outros feitos em pauta com prioridade maior, ou podese dizer também que tenha até perdido o próprio objeto. Logo, caso não venha a ser julgada não saberemos o definitivo posicionamento do STF sobre a mutação ou não do artigo 52, X, e nem sobre o real papel do Senado Federal no processo de controle da constitucionalidade.

Fizemos aquela afirmação (perda do objeto) tendo em vista o advento da Súmula Vinculante $n^{\circ}$ 26, editada em 16 de dezembro de 2009, que tem íntima conexão temática com a reclamação e, ainda, a inovação trazida pela lei 11.464, de 2007 que alterou a lei 8.072/90.

Antes de aprofundar o tema da suposta mutação constitucional sofrida pelo artigo 52, X da Constituição da República, necessário fazer um breve resumo acerca dos fatos que levaram a Defensoria Pública da União a ajuizar reclamação constitucional contra a decisão de um juiz de direito. 
O Supremo Tribunal Federal, em 23 de fevereiro de 2006, julgou o Habeas Corpus $\mathrm{n}^{\circ}$ 82.959/SP em que foi declarada incidenter tantum a inconstitucionalidade do artigo $2^{\circ}, \S 1^{\circ}$ da lei $8.072 / 1990$ que vedava a progressão de regime para os condenados pela prática de crimes hediondos ou equiparados. A Corte entendeu que a vedação à progressão de regime constante da "lei de crimes hediondos" violava o princípio da individualização da pena presente no artigo $5^{\circ}$, XLVI da Constituição Federal. Assim, foi concedida a ordem para que o paciente tivesse direito à progressão no regime de cumprimento da pena.

A partir daquele precedente (HC 82.959/SP) a Defensoria Pública da União requereu junto ao Juízo de Execuções Penais da Comarca de Rio Branco/AC que fosse concedido o mesmo benefício aos seus assistidos, qual seja, o direito à progressão de regime, pois o óbice constante da lei 8.072/1990 havia sido declarado inconstitucional pelo plenário do Supremo Tribunal Federal.

Diante da negativa daquele juízo em deferir o pedido formulado, sob o argumento de ausência de resolução do Senado Federal suspendendo a eficácia do dispositivo e, ainda, que os efeitos da decisão proferida no HC 82.959 beneficiaram somente as partes processuais, a Defensoria Pública da União ajuizou Reclamação Constitucional com base no artigo 102, I, $l$ da $\mathrm{CF} / 88$.

O fundamento do pedido foi de que a decisão do Juiz de Direito da Vara de Execuções Penais teria violado a autoridade do acórdão proferido nos autos do HC 82.959/SP, o qual proclamou a incompatibilidade do art. $2^{\circ}, \S 1^{\circ}$ da lei 8.072/90 com a Constituição Federal.

Isso posto, não é a questão penal que aqui nos interessa, eis que no ano seguinte ao ajuizamento da reclamação o Congresso Nacional editou a lei 11.464/07 que deu nova redação ao artigo $2^{\circ}$ da lei de crimes hediondos, 
passando não mais a existir óbice legal à progressão de regime nos casos de condenados pela prática de crime hediondo ou equiparado. Essa alteração, de certa forma, evidenciou um Poder Legislativo atualizado com a jurisprudência da Corte Constitucional.

Por outro lado, o que mostra espanto é a edição da súmula vinculante $\mathrm{n}^{\mathrm{o}} 26$ aprovada por maioria de votos (10 x 1) em 16 de dezembro de 2009, ou seja, dois anos após o advento da lei 11.464/07, sendo, então, passível de questionamento a sua real necessidade ante a nova redação constante do artigo $2^{\circ}$ da lei 8.072/90 dada por aquele diploma legal.

Feitas tais observações, o que de fato interessa ao presente trabalho foi a inusitada tese suscitada por Gilmar Mendes acerca dos efeitos da decisão do STF no exercício do controle difuso e, ainda, a mutação sofrida pelo art. 52, X, CF/88, no que foi acompanhado pelo Min. Eros Roberto Grau.

Gilmar Mendes é relator da Reclamação 4.335/AC e, ao proferir seu voto, manifestou-se pela procedência do pedido formulado pelo reclamante porque a decisão do STF no HC 82.959/SP seria dotada de força vinculante e eficácia erga omnes, no que a negativa do reclamado (VEP da Comarca de Rio Branco) em observar a autoridade daquela decisão ensejaria a utilização da via escolhida.

O ministro-relator aduziu em seu voto que, independentemente da edição da resolução suspensiva pelo Senado, qualquer decisão do Supremo Tribunal sobre questão constitucional seria dotada de caráter vinculante, portanto deveria ser por todos observada, já que a atual conjuntura do ordenamento jurídico constitucional assim autoriza que seja. Relatou, ainda, que a previsão constitucional constante do artigo 52, inciso $\mathrm{X}$ seria ultrapassada e desnecessária, num quadro de uma verdadeira mutação constitucional. 
Sustentou que a única resposta justificável para a manutenção do instituto da suspensão pelo Senado fundava-se em razão de índole exclusivamente histórica, acrescentando que tal mecanismo mostra-se inadequado para assegurar eficácia geral ou efeito vinculante às decisões do STF que não declaram a inconstitucionalidade de uma lei, mas tão-somente fixam orientação constitucionalmente adequada ou correta, ou seja, nas hipóteses de interpretação conforme a constituição e declaração de inconstitucionalidade parcial sem redução de texto. Gilmar Mendes justificou a ineficiência do instituto afirmando que nesses casos o Tribunal não afasta a incidência do dispositivo impugnado, mas apenas de um de seus significados normativos, sendo desnecessária qualquer comunicação ao Senado.

Acrescentou, ainda, que a Constituição da República de 1988 deu primazia ao controle concentrado de constitucionalidade ao alargar o rol de legitimados para propositura da ação direta de inconstitucionalidade, permitindo que grande parte das controvérsias constitucionais relevantes sejam submetidas ao STF mediante processo de controle abstrato de normas. Com isso o constituinte originário teria restringido de maneira radical a amplitude do controle difuso de constitucionalidade.

Outro argumento levantado pelo ministro-relator foi o de que a própria jurisprudência da Corte já vinha entendendo pela equiparação dos efeitos das decisões proferidas nos processos de controle abstrato e concentrado, baseando sua asserção no fato de que muitos julgados do Supremo Tribunal já manifestavam a possibilidade dos órgãos fracionários dos outros tribunais utilizarem a decisão sobre a questão constitucional como fundamento das suas, prescindindo de submete-lá ao órgão especial ou ao plenário.

Com base nisso, o Ministro concluiu que sempre houve uma vinculação dos órgãos fracionários às declarações de inconstitucionalidade ou de constitucionalidade proclamadas incidenter tantum, o que justificaria 
a descabimento da participação do Senado Federal no processo de controle da constitucionalidade. Ademais, ressaltou, também, que o mecanismo presente no art. 52, X da CF, seria anacrônico.

Em artigo de sua autoria, que usou como fundamento de seu voto, reproduzindo-o integralmente, o Min. Gilmar Mendes assim se manifesta:

\begin{abstract}
"Esse entendimento marca uma evolução no sistema de controle de constitucionalidade brasileiro, que passa a equiparar, praticamente, os efeitos das decisões proferidas nos processos de controle abstrato e concreto. A decisão do Supremo Tribunal Federal, tal como colocada, antecipa o efeito vinculante de seus julgados em matéria de controle de constitucionalidade incidental, permitindo que o órgão fracionário se desvincule do dever de observância da decisão do Pleno ou do Órgão Especial do Tribunal a que se encontra vinculado. Decide-se autonomamente com fundamento na declaração de inconstitucionalidade (ou constitucionalidade) do Supremo Tribunal Federal proferida incidenter tantum" (Mendes, 2004, p. 157).
\end{abstract}

Neste ponto, cabe recordar o que foi dito no tópico 1.2 do Capítulo 1 acerca da cláusula de reserva de plenário: a melhor interpretação a ser dada aos artigos 97 da CF/88 e 481, parágrafo único do Código de Processo Civil é aquela que entende que a dispensa de remessa da questão constitucional ao órgão especial ou pleno do Tribunal diz respeito a uma liberalidade e não a uma vinculação do órgão fracionário, a fim de prestigiar-se um debate aberto e democrático acerca das questões constitucionais.

Oportuno trazer à tona a bem ponderada colocação feita pelo Professor Fábio Carvalho Leite, para quem:

\footnotetext{
“Afirmar que o órgão fracionário estaria vinculado à decisão do STF - por ser instância superior, órgão de cúpula do Poder Judiciário ou guardião da Constituição (argumento de que têm se valido alguns ministros para avocar ao STF praticamente um monopólio na interpretação do texto constitucional) subverteria de certo modo o sistema de controle de constitucionalidade brasileiro, pois uma decisão tomada pelo STF em controle concreto-difuso vincularia os tribunais (segunda instância), embora não afetasse os juízes de primeira instância”" (Leite, 2011, p. 215) (grifo nosso)

Conforme ressaltado por Fábio Leite no trecho acima transcrito, entender que o órgão fracionário estaria vinculado às decisões do órgão de cúpula é subverter o controle de constitucionalidade, pois, assim sendo, o juiz de primeira instância, de hierarquia inferior, teria liberdade para
} 
divergir do STF, enquanto que a Turma/Câmara, órgão de hierarquia superior, estaria vinculada à Corte. Se esta fosse a opção do legislador ordinário, atribuir efeitos vinculantes aos pronunciamentos do STF, teria incluído no texto do dispositivo processual civil (481, parágrafo único) os juízes de primeira instância também.

Se o Min. Gilmar Mendes entende que órgãos fracionários estão vinculados à decisão do STF, então por que o juiz da Vara de Execuções Penais (primeira instância) também estaria? Esse não é um órgão monocrático que decide tanto sobre a questão incidental quanto sobre o pedido principal?

Desse modo, o voto do ministro-relator pela procedência da reclamação mostra-se um tanto controverso, eis que foi ajuizada contra a decisão de um juiz e não contra um acórdão proferido pelo Tribunal.

Ademais, sustentou, ainda, que as alterações trazidas pela lei 9.756/1998 contribuíram para ampliar os efeitos da decisão tanto nas hipóteses de declaração de inconstitucionalidade incidental quanto nos casos de fixação de uma dada interpretação constitucional pelo Tribunal, destacando o conteúdo do $\S 1$-A do artigo 557 do CPC que autoriza o relator, mediante decisão unipessoal, a dar provimento ao recurso, se a decisão recorrida estiver em manifesto confronto com jurisprudência dominante ou súmula da Corte.

Antes do advento do citado diploma que alterou a legislação processual civil, a lei 8.038/1990, que regula os procedimentos perante o STF e o STJ, já adotava mecanismo idêntico em seu artigo 38, só que restrito àquelas instâncias superiores.

Contudo, a conclusão do Ministro acerca da suposta ampliação dos efeitos parece estar equivocada, pois o legislador infraconstitucional, no texto do art. 557, § 1-A, não se referiu única e exclusivamente ao Supremo Tribunal Federal - ali também incluiu todos os Tribunais Superiores. Uma 
vez mais, se o legislador tivesse optado por atribuir efeitos vinculantes tãosó às decisões da Corte Suprema, não teria se valido da expressão "ou de outro Tribunal Superior". Como não bastasse isso, da decisão monocrática que julgar o recurso caberá agravo no prazo de 5 (cinco) dias, conforme dispõe o artigo 557, $\S 1^{\circ}$ do CPC.

Depreende-se, com isso, que a intenção do legislador ao editar a Lei 9.756/98 foi a de dar primazia aos princípios da economia processual, celeridade e segurança jurídica, buscando uma coerência/uniformização nas decisões dos Tribunais do país, e não de submetê-las/vinculá-las ao que for decidido pelo Supremo Tribunal Federal, que passaria a deter um monopólio da interpretação constitucional.

Portanto, conforme afirmamos no Capítulo 1 houve, sim, certa aproximação dos meios de controle da constitucionalidade no sistema brasileiro, mormente após as reformas infraconstitucionais (leis 9.756/98 e 11.418/06). Todavia, afirmar que estamos diante de uma objetivação ou "dessubjetivação" das decisões do STF no controle incidental, que passariam a ter uma eficácia ultra partes, é um exagero, é ir além do texto constitucional e infraconstitucional, tendo em vista que a atual Carta Política somente prevê esses efeitos no controle exercido por via de ação direta (artigo 102, $\S 2^{\circ}$ ).

Outro argumento, bastante interessante, colocado pelo ministrorelator na reclamação diz respeito ao exercício do controle de constitucionalidade nas ações coletivas. Assim, afirmou que nesses casos "somente por força de uma compreensão ampliada ou do uso de uma figura de linguagem pode-se falar em decisão com eficácia inter partes" (Mendes, 2004, p. 162), concluindo que, nessas hipóteses, a suspensão da lei pelo Senado revela-se inútil caso se entenda que ela tem uma outra função que não a de atribuir publicidade à decisão declaratória de ilegitimidade. 
Cita como exemplo a declaração de inconstitucionalidade incidental proferida no bojo de uma ação civil pública, defendendo que tal decisão já tem eficácia contra todos per si, tendo em vista o artigo 16 da lei 7.347/85, o qual dispõe que a sentença civil fará coisa julgada erga omnes, dificultando a justificativa da necessidade de comunicação ao Senado Federal em tais casos.

No entanto, a expressão inter partes não significa que a relação processual necessariamente precise ser entre sujeitos determinados. Não é porque uma das partes representa uma coletividade - por exemplo, cidadãos de um dado Município representados pelo Ministério Público - que não se poderá falar em eficácia inter partes, até porque uma decisão de inconstitucionalidade proferida pelo STF em ação civil pública terá apenas efeitos para as partes que litigaram em juízo. Portanto, cidadãos de outro Município não poderão se beneficiar daquela decisão, pois seus efeitos não possuem amplitude erga omnes.

Esse entendimento é ratificado pelo artigo 16 da lei 7.347/85, que preconiza que a sentença fará coisa julgada nos limites da competência territorial do órgão prolator.

Art. 16. A sentença civil fará coisa julgada erga omnes, nos limites da competência territorial do órgão prolator, exceto se o pedido for julgado improcedente por insuficiência de provas, hipótese em que qualquer legitimado poderá intentar outra ação com idêntico fundamento, valendo-se de nova prova. (grifo nosso)

Cabe lembrar que o controle de constitucionalidade exercido no bojo de uma ação civil pública é exercido como pressuposto lógico e necessário para solução do caso concreto. Ao contrário, estaríamos diante de uma usurpação de competência, pois somente a Corte Suprema tem a prerrogativa para apreciar a constitucionalidade de lei in abstracto como pedido principal. Segundo Pedro Lenza: 
“(...) a ação civil pública não pode ser ajuizada como sucedâneo de ação direta de inconstitucionalidade, pois em caso de produção de efeitos erga omnes, estaria provocando verdadeiro controle concentrado de constitucionalidade usurpando competência do STF (...)" (Lenza, 2010, p. 237) (grifo nosso)

Com efeito, a decisão sobre a matéria constitucional por ser prejudicial ao exame do mérito não produzirá eficácia erga omnes, somente podendo-se falar em tais efeitos com relação ao dispositivo da sentença (art. 469 , inc. III, CPC).

Portanto, também em sede de ação civil pública ou outra espécie de ação coletiva há de falar-se tanto em efeito entre as partes do caso concreto quanto em comunicação ao Senado Federal a fim de que edite resolução para retirar do ordenamento jurídico a lei ou ato normativo declarado inconstitucional.

O Ministro Gilmar Mendes encerrou seu voto justificando que diante dessa atual realidade no ordenamento jurídico e da nova compreensão que se conferiu à regra contida no artigo 52, $\mathrm{X}$, da Constituição Federal poderia se falar em uma autêntica mutação constitucional. Em outras palavras, de uma reforma da Constituição sem modificação do texto que passaria a atribuir uma nova competência ao Senado Federal que não mais a de suspender a execução da lei declarada inconstitucional por decisão definitiva do STF, mas sim de dar publicidade a essa através de publicação no diário oficial do Congresso.

Acompanhando a tese sustentada pelo relator da reclamação, Eros Roberto Grau também defendeu a possibilidade de se atribuir ao Senado Federal o dever de fazer publicar a decisão do STF, vendo no texto normativo do artigo 52, $\mathrm{X}$ uma nova competência. $\mathrm{O}$ ministro sustentou em seu voto-vista que o que pretendeu Gilmar Mendes não foi propor uma simples interpretação do texto normativo, foi mais do que isso. Tratou-se de uma verdadeira mutação constitucional, pela qual se altera o conteúdo da Constituição, contudo sem mexer na literalidade do texto. Em suma, na mutação, sob a ótica do Ministro, não apenas a norma é nova, mas o próprio 
texto normativo é substituído por outro. Eros Grau chegou a propor como deveria ser o novo enunciado normativo:

"O exemplo que no caso se colhe é extremamente rico. Aqui passamos em verdade de um texto [compete privativamente ao Senado Federal suspender a execução, no todo ou em parte, de lei declarada inconstitucional por decisão definitiva do Supremo Tribunal Federal] a outro texto [compete privativamente ao Senado Federal dar publicidade à suspensão da execução, operada pelo Supremo Tribunal Federal, de lei declarada inconstitucional, no todo ou em parte, por decisão definitiva do Supremo]" (Grau, 2007, p. 9-10) (grifo nosso)

Após discorrer sobre a origem da mutação constitucional e no que ela consiste, o ministro chegou à conclusão de que o texto do inciso $\mathrm{X}$ do artigo 52 seria obsoleto.

Reiterou o entendimento manifestado pelo ministro-relator de que a recusa do juízo reclamado em conceder a progressão de regime, no caso de crimes hediondos, requerida pelo reclamante, desrespeitou a eficácia erga omnes que deveria ser atribuída à decisão do Supremo Tribunal Federal no HC 82.959 que declarou a inconstitucionalidade do artigo $2^{\circ}, \S 1^{\circ}$, da Lei n.8.072/1990. Assim, Eros Grau posicionou-se pela procedência da Reclamação.

Além dos 2 (dois) votos acima sintetizados, também se manifestaram na Reclamação os ministros Sepúlveda Pertence e Joaquim Barbosa, contudo em sentido contrário, ou seja, pela sua improcedência.

O Ministro Sepúlveda Pertence iniciou seu voto elogiando a dissertação dos seus colegas. Porém, ao mesmo tempo, alertou para o perigo da proposta que foi feita acerca da mutação constitucional, pois, na sua visão, daria ao Tribunal um amplo poder. Além disso, destacou que, sob a ótica dos mais radicais, poderia aquela proposta "ter o cheiro de golpe de Estado", já que o Poder Judiciário não estaria imune às tentações do golpe de Estado, sendo, então, para o Ministro, "essencial a elas resistir".

Sustentou, ainda, que o fato de a jurisprudência do Tribunal vir se manifestando pela possibilidade de dispensa da reserva de plenário nos 
demais tribunais, quando já houvesse decisão pela inconstitucionalidade proferida incidentalmente pelo pleno do Supremo, não justificaria reduzir a nada o papel do Senado no processo de controle de constitucionalidade.

Assim se manifestou:

"Traço outras considerações no sentido da decisão que, então, se tomou e que, depois, se consolidaria no Tribunal a partir do acórdão do Ministro Ilmar Galvão de dispensar a reserva de Plenário nos demais tribunais, se já houvesse decisão incidente do Supremo declaratória da inconstitucionalidade da lei ou do ato normativo de que de cuidasse.

Mas, partir daí, a reduzir-se a nada o papel do Senado - que todos os textos constitucionais subseqüientes a 1934, com exceção do Estado Novo, mantiveram - parecem-me ir, com todas as vênias, além da marca" (Pertence, 2007, p. 3-4) (grifo nosso).

Sepúlveda Pertence, ao contrário do proposto por Gilmar Mendes e

Eros Grau, busco uma solução na própria Constituição, e para isso afirmou que a Emenda Constitucional no 45/2004 dotou o STF de um poder que, sem reduzir o Senado a um órgão de mera publicidade das decisões da Corte, dispensaria a intervenção dessa casa legislativa para fins de efeitos vinculantes. Isso seria plenamente possível através da edição de súmula vinculante, já que dotada de eficácia erga omnes e efeito vinculante.

Necessário trazer à tona, uma vez mais, a posição do Min. Sepúlveda Pertence ao proferir seu voto na Rcl. 4335-5:

\footnotetext{
"A Emenda Constitucional 45 dotou o Supremo Tribunal de um poder que, praticamente, sem reduzir o Senado a um órgão de mera publicidade de nossas decisões, dispensa essa intervenção. Refiro-me, é claro, ao instituto da súmula vinculante, que a Emenda Constitucional 45, de 2004, veio a adotar depois de mais de uma década de tormentosa discussão. De tal modo que reproduzirei no meu voto, para efeitos didáticos, o dispositivo do vigente art.102, $\S 3^{\circ}$, que vincula, ele sim, a súmula vinculante, editada na conformidade da Lei de 2006, que a disciplinou. Vincula, nos termos da Constituição, sim, não apenas os tribunais, no que o eminente Ministro Gilmar Mendes, cada vez mais religioso, chama de efeitos transcendentes, mas este restrito aos tribunais que tenham de enfrentar a mesma questão de inconstitucionalidade. E tenho dúvidas se até aí seria vinculante, porque a dispensa da remessa ao Plenário da argüição de inconstitucionalidade não impede o tribunal inferior de alterá-la enquanto não dotada a jurisprudência do Supremo Tribunal do efeito vinculante, que, ou decorre, no nosso sistema, de decisões nos processos objetivos de controle direto, ou decorrerá da adoção solene, pelo Tribunal, da súmula vinculante" (Pertence, 2007, p. 4-5) (grifo nosso).
} 
Por derradeiro, alertou para uma possível enxurrada de reclamações caso venha a se confirmar o entendimento de que qualquer decisão da Corte, no exercício do controle difuso, tem força normativa suficiente para suspender a execução da lei.

Após o voto de Sepúlveda Pertence, foi a vez do Min. Joaquim Barbosa, que, assim como aquele, não conheceu da reclamação. Alegou que a suspensão da execução da lei pelo Senado não representaria obstáculo à ampla efetividade das decisões da Corte Constitucional, mas um complemento.

Dessa forma, imprescindível seria, para o ministro, a manutenção da leitura tradicional do artigo 52, X, CF/88. Descartou, ainda, a ocorrência da alegada mutação sofrida pelo dispositivo, afirmando que com a proposta do relator ocorreria, pela via interpretativa, tão-somente a mudança no sentido da norma constitucional em questão, e, que, ainda que se aceitasse a tese da mutação, esta careceria de dois fatores adicionais: a) o decurso de um espaço de tempo maior para a verificação da mutação; e b) o consequente e definitivo desuso do dispositivo.

Portanto, para Joaquim Barbosa, a mutação constitucional não deve ser compreendida como uma forma de se tentar corrigir a Constituição, substituindo um texto por outro, mas como um mecanismo a ser utilizado pelo intérprete com o fim de atribuir um novo significado, sentido ao texto legal.

Por fim, Joaquim Barbosa ressaltou que essa proposta, além de estar impedida pela literalidade do art. 52, X, iria na contra mão das conhecidas regras de auto-restrição.

Percebe-se, a partir da análise dos 4 (quatro) votos acima expostos, que há uma clara divergência acerca do tema da abstrativização do controle difuso, em que de um lado encontram-se os Ministros Gilmar Mendes e Eros Graus, defendendo a transcendência dos efeitos da decisão proferida 
no caso concreto, seja ela pela constitucionalidade ou inconstitucionalidade, sob o argumento da mutação constitucional. De outro lado, os Ministros Sepúlveda Pertence e Joaquim Barbosa preservando a manutenção da participação do Senado Federal, acrescentando, ainda, a possibilidade de utilização da súmula vinculante para alcançar-se os mesmos objetivos pretendidos pela tese da abstrativização.

Conforme já ressaltado no início do presente capítulo, dificilmente o Supremo Tribunal Federal irá concluir o julgamento da Reclamação 4.3355/AC, tendo em vista dois motivos: (i) a devida alteração na legislação sobre crimes hediondos que adotou o entendimento da Corte acerca da possibilidade de progressão de regime, evidenciando, de tal maneira, uma escolha do Poder Legislativo em não suspender o dispositivo proclamado inconstitucional, mas compatibilizá-lo à luz da Constituição Federal; e (ii) a edição da súmula vinculante $\mathrm{n}^{\circ} 26$ que foi aprovada pelo plenário da Corte em dezembro de 2009. Tais motivos levam a crer que o objeto daquela ação não mais existe, logo não há interesse de agir (art. 267, VI, CPC).

Feitas essas considerações, o tema da abstrativização suscitado pelo relator da reclamação, sob o argumento da mutação constitucional, ainda que não seja uma realidade entre os ministros da Corte, já desperta muitas críticas por parte da doutrina, havendo autores que a defendem (Luis Roberto Barroso; Gilmar Mendes; Teori Albino Zavascki) e outros que sustentam sua impossibilidade (Lênio Luiz Streck; Pedro Lenza; Nelson Nery Junior), sendo então necessária uma análise acerca das consequências de sua eventual concretização no ordenamento jurídico pátrio.

\subsection{Senado Federal como diário oficial das decisões proferidas pelo STF no controle difuso: uma nova atribuição.}

Gilmar Mendes, em artigo de sua autoria, reproduzido na íntegra em seu voto, afirma que já houve uma tentativa de se atribuir ao Senado da República a função de fazer publicar no diário do Congresso a decisão 
incidental de inconstitucionalidade proferida pelo STF, o que configuraria nova disciplina ao instituto da suspensão. Isso se deu no Projeto que resultou na Emenda Constitucional n. 16/65 e a proposta era de que o artigo 64 da Constituição tivesse a seguinte redação:

“Art. 64: Incumbe ao Presidente do Senado Federal, perdida a eficácia de lei ou ato de natureza normativa (art. 101, § $3^{\circ}$ ), fazer publicar no Diário Oficial e na Coleção das leis, a conclusão do julgado que lhe for comunicado."

Todavia, conforme informa o ministro, aquela proposta de alteração do disposto no artigo 64 da Constituição de 1946, com atribuição de eficácia erga omnes à declaração de inconstitucionalidade proferida pelo STF, foi rejeitada, confirmando-se a tradição iniciada em 1934 de outorga ao poder legislativo de suspender a execução do ato normativo proclamando inconstitucional.

Na década de setenta o STF começou a manifestar-se pela dispensabilidade de intervenção do Senado Federal nos casos de declaração de inconstitucionalidade de lei proferida em sede de Representação de Inconstitucionalidade, já que se tratava de controle abstrato, tendo por si só a capacidade de produzir efeitos vinculantes contra todos.

Com isso, decorridos mais de setenta anos da criação do instituto de participação do Senado Federal, percebe-se a opção do legislador constituinte em manter o legislativo no processo de controle de constitucionalidade das leis, somente autorizando-se a eficácia erga omnes quando editada a competente resolução suspendendo a execução do diploma legal.

Não obstante as críticas formuladas pelos ministros do Supremo Tribunal de ser o procedimento previsto no art. 52, X da CF/88 um instrumento obsoleto, a suspensão continua a ser um importante mecanismo de proteção da supremacia da Constituição Federal, o qual deve ser preservado e mantido, até ulterior reforma constitucional que venha a suprimi-lo. 
Outro importante argumento a ser destacado diz respeito à discricionariedade da suspensão pelo Senado Federal, pois em determinadas hipóteses a eventual suspensão da execução da lei proclamada inconstitucional, suponhamos que por uma maioria apertada de votos $(6 \times 5)$, poderá trazer prejuízos para a sociedade brasileira, e nesse caso, aquela casa legislativa, ainda que recebida a comunicação pelo Tribunal, optará por não editar a resolução suspensiva. Sendo o Senado uma casa de representação política da sociedade, não poderá ir contra os anseios dessa.

Aproveitando-se do que acima foi exposto, de fato, uma decisão tomada por uma maioria apertada (6x5) não traduz a desejada segurança jurídica tão defendida por aqueles que sustentam a eficácia vinculante das decisões do Supremo Tribunal no exercício do controle difuso, de modo que aquele entendimento poderia ser facilmente alterado em julgamento futuro, tendo em vista, por exemplo, uma mudança na composição da Corte.

Daí que não há prazo para edição da Resolução do Senado, podendo essa casa legislativa esperar por uma nova decisão acerca da mesma questão constitucional, dessa vez, dotada de maior segurança, para só então exercer sua competência privativa de suspender a execução da lei proclamada inconstitucional por decisão definitiva do STF.

Ponto que merece destaque é o fato de o mecanismo previsto no artigo 52, X da CF/88 permitir uma fiscalização acerca da decisão proferida pelo STF, pois o Senado Federal antes de optar por editar a competente resolução suspensiva deverá examinar os pressupostos formais daquela. Em suma, verificar se houve observância ao princípio do devido processo legal e se a cláusula de reserva de plenário foi respeitada, e, havendo ofensa a alguma dessas regras, não poderá atribuir efeitos ultra partes ao julgado.

Portanto, defender que ao Senado Federal compete apenas dar publicidade às decisões da Corte Suprema é acabar com essa fiscalização instituída pelo poder constituinte originário e, ao mesmo tempo, submeter a 
sociedade brasileira a uma certa insegurança jurídica, visto que uma decisão tomada por 6 (seis) votos a 5 (cinco) passaria a ter um caráter obrigatório e vinculante.

Assim sendo, a proposta de mutação constitucional e, por conseguinte, de atribuir ao Senado da República uma nova competência, qual seja, a de fazer publicar no Diário Oficial do Congresso a decisão do Supremo Tribunal sobre a questão constitucional, é ofender a literalidade do artigo 52, X, além de transformar o Senado em uma espécie de diário oficial do STF.

Oportuno, neste momento, colacionar trecho do artigo do jurista Lênio Luiz Streck, em parceria com outros autores, no qual critica a tese suscitada na Reclamação 4.335/AC, além de alertar para algumas graves consequências:

\begin{abstract}
"Mas o modelo de participação democrática no controle difuso também se dá, de forma indireta, pela atribuição deixada ao Senado Federal. Excluir a competência do Senado Federal - ou conferir-lhe apenas um caráter de tornar público o entendimento do Supremo Tribunal Federal - significa reduzir as atribuições do Senado Federal à de uma secretaria de divulgação intra-legislativa das decisões do Supremo Tribunal Federal; significa, por fim, retirar do processo de controle difuso qualquer possibilidade de chancela dos representantes do povo deste referido processo, o que não parece ser sequer sugerido pela Constituição da República de 1988.

Como se não bastasse reduzir a competência do Senado Federal à de um órgão de imprensa, há também uma consequência grave para o sistema de direitos e garantias fundamentais. Dito de outro modo, atribuir eficácia erga omnes e efeito vinculante às decisões do STF em sede de controle difuso de constitucionalidade é ferir os princípios constitucionais do devido processo legal, da ampla defesa e do contraditório (art. $5^{\circ}$, LIV e LV, da Constituição da República), pois assim se pretende atingir aqueles que não tiveram garantido o seu direito constitucional de participação nos processos de tomada da decisão que os afetará. Não estamos em sede de controle concentrado!" (Streck, et al., 2011, p. 7-8) (com os grifos).
\end{abstract}

Por derradeiro, outro argumento utilizado pelos ministros do Supremo para defender o fim da participação do Senado no processo de controle de constitucionalidade difuso é a morosidade em se editar a resolução suspensiva, o que acarretaria sérias consequências para os particulares que não estão abarcados pela decisão proferida no caso concreto, 
No entanto, alguns estudos, com base em estatísticas, apontam que há sim uma atuação do Senado no processo de edição da resolução suspendendo a execução de atos normativos declarados inconstitucionais pela via incidental, havendo, na verdade, pouca comunicação entre o Tribunal Constitucional e aquela casa legislativa acerca das questões constitucionais.

A professora Flavia Bahia, em seu livro de Direito Constitucional, ao tecer críticas à tese da abstrativização, faz menção ao estudo feito por um estudante de direito que analisou dados estatísticos sobre as comunicações feitas pelo STF ao Senado, assim se manifestando:

“c) Em acurada pesquisa sobre o tema, Carlos Victor Nascimento detectou que não é prática reiterada do Senado Federal deixar de expedir resoluções suspendendo eficácia de lei ou ato normativo declarado inconstitucional. Em sua pesquisa, apurou que dos 372.961 recursos extraordinários constantes na base de dados do STF, de 1989 a 2009, 97.130 foram providos, total ou parcialmente, quer seja de forma monocrática, quer por Turma ou Plenário, e 5.192 foram não providos. Desses 97.130 REs, identificaram-se apenas 165 REs em que houve comunicação ao Senado, conforme determina o regimento interno da Corte. Desses 165 recursos, uma média de 136 tratavam da inconstitucionalidade da lei e, em 95 delas, o Senado expediu resolução suspendendo a eficácia da lei ou ato normativo declarado inconstitucional pelo plenário do STF, o que equivale a $70 \%$ das comunicações feitas, ou seja a sua atuação não é obsoleta como defendem os Ministros Gilmar Mendes e Eros Grau, o que surpreende é o baixo número de comunicações feitas pelo STF ao Senado com base nos números analisados!" (Martins, 2011, p. 516-517) (com os grifos).

Outro importante estudo foi o desenvolvido pela aluna Maristela Seixas Dourado do curso de pós-graduação lato-sensu em Direito Legislativo, em que, também abordando o tema da participação do Senado Federal no controle de constitucionalidade das leis, analisou importantes dados estatísticos acerca das comunicações feitas pelo STF e sobre a posterior edição de resolução suspensiva. Assim, cabe destacar o que concluiu a partir de sua pesquisa:

"No levantamento efetuado por este trabalho, dos 184 casos apresentados ao Senado Federal pelo Supremo Tribunal Federal, no período de 1988 até outubro de 2008, declarando leis total ou parcialmente inconstitucionais, podemos concluir que houve manifestação do Senado em $68 \%$ dos casos, resultando em 124 resoluções que acompanharam o posicionamento da 
Suprema Corte. Dos processos arquivados, conferimos que, com exceção de apenas uma comunicação da Suprema Corte, sobre a qual o Senado Federal não acompanhou a declaração feita pelo Supremo Tribunal, todas foram arquivadas tendo em vista a demora na análise pela Comissão de Constituição e Justiça daquela Casa Legislativa. Outro dado interessante diz respeito ao universo de leis declaradas inconstitucionais pela Suprema Corte, 136 casos foram decorrentes de leis elaboradas pelos estados contra 48 leis federais. Das resoluções publicadas pelo Senado Federal, constatamos que o estado de São Paulo, seguido por Rio Grande do Sul, Santa Catarina, Rio de Janeiro, Pernambuco e Minas Gerais, com $32,14,8,8,5$ e 4 , respectivamente, foram as unidades federadas que mais cometeram inconstitucionalidades no momento de sua formulação de suas leis" (Dourado, 2008, p. 68) (grifo nosso).

Logo, um tanto equivocado o argumento de um legislativo omisso quanto à função que lhe atribui a Constituição Federal em seu artigo 52, X. Vislumbra-se, na verdade, uma falta de cooperação entre os poderes Judiciário e Legislativo sobre o tema. Problema esse que não pode ser resolvido a partir de uma tese arbitrária e sem fundamento jurídico como a da mutação constitucional, que coloca em risco o princípio da separação dos poderes e o salutar sistema de freios e contrapesos, além de concentrar em um único órgão (STF) a interpretação da Lex Max.

Com base nisso, mostra-se muito mais saudável um diálogo constante entre STF e o Senado da República, a fim de aprimorar a regra constante do artigo 52, $\mathrm{X}, \mathrm{CF} / 88$, de tal modo que todos sejam contemplados, principalmente a sociedade brasileira, que será a mais beneficiada a partir dessa integração.

\subsection{Fim do sistema misto (?): a equiparação dos efeitos da decisão nos controles concreto-difuso e abstrato-concentrado.}

Os efeitos da decisão no controle abstrato-concentrado de constitucionalidade são, via de regra, retroativos, a exceção está prevista na lei 9.868/99 (art. 27), e fazem coisa julgada material erga omnes, pois o pedido principal da ação é a análise da questão constitucional à luz da Constituição da República. Assim é que, nessa espécie, não há que se falar no procedimento previsto no artigo 52, $\mathrm{X}$ da Lei Maior. Por outro lado, no controle concreto-difuso a decisão proferida terá efeitos retroativos no 
limite da relação processual, e não faz coisa julgada material (469, III do CPC), visto que o objeto da ação não é a declaração de inconstitucionalidade, essa é decidida incidentalmente, como causa de pedir. Somente admite-se efeitos ultra partes quando feita a comunicação ao Senado Federal e, após analisar os pressupostos formais da decisão, resolver editar resolução suspendendo a execução do ato proclamado inconstitucional.

Há, então, nítidas diferenças entre um mecanismo e outro de controle da constitucionalidade, cada qual com suas características específicas, mas tendo em comum a verificação da compatibilidade de lei ou normativo com a Constituição Federal.

Não se pode ignorar que desde a origem do controle abstrato de constitucionalidade em 1965, com a Emenda Constitucional n. 16, até os dias atuais, houve, de fato, uma prevalência desse em relação ao controle difuso, pois as inovações ocorridas, principalmente, no âmbito constitucional assim o fizeram, mas daí a afirmar que os efeitos de um equivalem ao do outro, melhor dizendo, que ambos possuem efeitos vinculantes por si só, é ir contra a tradição brasileira de controle da constitucionalidade.

Portanto, entender que uma decisão em sede controle difuso tem a mesma eficácia que uma proferida em controle concentrado faz cair por terra a própria diferença.

A atual Carta Magna somente prevê efeitos vinculantes contra todos oriundos do órgão de cúpula do Poder Judiciário em duas situações específicas, a saber: (i) em se tratando de controle pela via direta (ADIn, $\mathrm{ADC}$ e $\mathrm{ADPF}$ ) ou (ii) pela edição da chamada súmula vinculante. Isso implica dizer, conforme já ressaltado, que não há previsão constitucional determinando que as decisões resolvidas incidentalmente pelo Supremo Tribunal sejam autonomamente dotadas dos mesmos efeitos das decidas no 
controle abstrato, exceto quando, proclamada a inconstitucionalidade da lei ou do ato normativo, o Senado edite resolução suspensiva, fazendo com que aquela decisão antes dotada de eficácia limitada para as partes passe a ser por todos de observância obrigatória.

Ademais, as reformas que ocorreram no âmbito da legislação processual civil, por mais que tenham aproximado os dois sistemas de controle da constitucionalidade, não tiveram o condão de atribuir eficácia vinculante às decisões do STF. É muito mais coerente o entendimento de que aquelas reformas objetivaram tão-somente a busca da desejada racionalização orgânica da instituição judiciária brasileira, caso contrário seriam passíveis de questionamento diante de eventual ofensa ao texto constitucional.

O legislador constituinte não adotou a doutrina americana do stare decisis no controle difuso de constitucionalidade, segundo a qual as decisões proferidas pela Suprema Corte acerca da questão constitucional são dotadas de eficácia erga omnes. Ou seja, o precedente tem força de regra jurídica devendo ser seguido pelos demais órgãos do Poder Judiciário. Entender como o ministro-relator fez na Reclamação 4.335/AC, de que o juiz de primeira instância desrespeitou a eficácia erga omnes de uma decisão proferida no bojo de um Habeas Corpus, como questão prejudicial, é adotar a regra do stare decisis, além de restringir a autonomia dos magistrados na atividade de interpretação do texto constitucional, já que qualquer decisão contrária ao precedente da Corte ensejaria o ajuizamento de reclamação a fim de assegurar a sua autoridade.

Dessa forma, afigura-se faltar, ao menos em sede de controle difuso, dispositivos e regras, sejam constitucionais, sejam processuais, para a implementação da tese da abstrativização do controle difuso.

Por fim, a possibilidade de se conseguir o objetivo pretendido, qual seja, a vinculação dos demais órgãos ao entendimento da Corte acerca da 
interpretação constitucional, mostra-se viável mediante a edição de súmula vinculante, o que seria muito mais legítimo e eficaz, além de respeitar a segurança jurídica, evitando o casuísmo. O instrumento da súmula vinculante surgiu com o advento da Emenda Constitucional n. 45/04 e para ser editada exige-se a necessidade de reiteradas decisões sobre matéria constitucional controvertida.

A lei 11.417/06 que disciplina a edição, a revisão e o cancelamento de enunciado de súmula vinculante, em seu artigo $2^{\circ}, \S 1^{\circ}$, assim dispõe sobre seu objeto:

"O enunciado da súmula terá por objeto a validade, a interpretação e a eficácia de normas determinadas, acerca das quais haja, entre órgãos judiciários ou entre esses e a administração pública, controvérsia atual que acarrete grave insegurança jurídica e relevante multiplicação de processos sobre idêntica questão."

Eis, portanto, uma ótima alternativa a ser adotada pela Corte a fim de atribuir um caráter vinculante às suas reiteradas decisões sobre matéria constitucional, contornando-se, assim, eventual morosidade do Senado Federal em editar a resolução suspensiva.

A súmula vinculante não é apenas uma alternativa a tese da abstrativização, na verdade, evidencia que somente por meio dela se poderá atribuir efeitos vinculantes aos julgados da Corte no controle difuso. Não é razoável admitir que uma decisão casuística, ainda não amadurecida, produza os mesmos efeitos de uma súmula vinculante, sem que haja qualquer previsão constitucional ou legal que assim autorize que seja.

Contudo, na hipótese de advento da resolução de que trata o artigo 52, $\mathrm{X}, \mathrm{CF} / 88$ prescindível será a edição de súmula vinculante pelo $\mathrm{STF}$, visto que o resultado a ser alcançado por ambos os institutos será o mesmo. De igual forma, caso o Senado da República opte por alterar a lei, mediante apresentação de Projeto, conforme se deu no caso da progressão de regime, a fim de sanar o vício existente, desnecessária a edição de súmula vinculante. 
Apenas para rememorar, a edição da súmula vinculante n. 26 mostrou-se prescindível ante o advento da lei 11.464/07 que veio a adotar o mesmo entendimento da Suprema Corte acerca da progressão de regime para os condenados por crime hediondo ou equiparado. Com isso, o Congresso Nacional optou por modificar o parágrafo $1^{\circ}$ do artigo $2^{\circ}$ da lei 8.072/90 ao invés de editar resolução suspendendo a sua eficácia.

No mais, a segurança se completa com exigência do quorum qualificado de 2/3 (dois terços) para edição da súmula vinculante, mais seguro, para efeitos de abstrativização, do que o quorum normal do controle difuso que é o de maioria absoluta.

No julgamento do HC 82.959/SP (2006) o plenário do STF proclamou a inconstitucionalidade de dispositivo da lei de crimes hediondos por 6 (seis) votos a 5 (cinco), evidenciando uma dissidência acerca do tema. Caso esse fosse o mesmo placar para a edição de uma súmula vinculante, a proposta não seria aprovada e o tema continuaria em aberto. Porém, em dezembro de 2009 o Supremo Tribunal Federal, por maioria de votos, vencido o Ministro Marco Aurélio, aprovou a súmula vinculante n. 26 que consolidou o entendimento fixado naquele remédio constitucional julgado 3 (três) anos antes, demonstrando um amadurecimento acerca do tema.

Uma decisão por 10 (dez) votos a 1 (um) demonstra maior segurança jurídica do que uma por 6 (seis) a 5 (cinco), assim como o resultado mínimo, 8 (oito) votos a 3 (três) exigido pela Constituição Federal para aprovar-se uma súmula vinculante, também expõe uma certa homogeneidade acerca da questão constitucional (art. 103-A).

Evidente que, com isso, queremos alertar para o perigo de uma eventual concretização da tese suscitada na Reclamação Constitucional 4.335, eis que decisões casuísticas e tomadas por maioria apertada não devem ter status de uma decisão proferida pela via do controle direto de constitucionalidade. 
Apenas uma suposição, mas que acreditamos que valha a pena ser colocada, é que, com base no que foi exposto, pode-se inferir que das vezes que o Senado Federal omitiu-se do dever de editar a resolução prevista no artigo 52, X da Constituição da República, o tenha feito por razões de segurança jurídica, talvez acreditando que a decisão proferida pela Suprema Corte não tivesse sido tomada por quorum considerado ideal pela Casa Legislativa.

Por derradeiro, o entendimento do Min. Gilmar Mendes ao julgar procedente a Reclamação, por entender que qualquer decisão proferida pelo plenário da Corte acerca de matéria constitucional é dotada de efeito vinculante, não inviabiliza o exercício do controle difuso por juízes ou tribunais, eis que não há nenhum mecanismo no ordenamento jurídico que os impeça de excercê-lo. Todavia, a decisão que estiver em desacordo com o precedente será passível de questionamento por via da Reclamação Constitucional, restringindo consideravelmente a liberdade de interpretação por parte dos demais órgãos integrantes do Poder Judiciário.

Logo, ainda que se fale em equiparação dos efeitos do controle concreto aos do controle abstrato, aquele continuará existindo, não tendo lógica a afirmação de um possível fim do sistema misto de controle da constitucionalidade, característica essa peculiar no Brasil desde 1965.

A suposta mutação constitucional sofrida pelo artigo $52, \mathrm{X}$ da $\mathrm{CF} / 88$ evidencia uma interpretação equivocada do texto constitucional, pois defender-se a substituição de um texto por outro, construído pelo próprio intérprete, como o fazem alguns ministros do Supremo, é ultrapassar o molde, os limites a que estão adstritos tanto o Poder Judiciário quanto a própria Ciência do Direito. Tanto um quanto outro constroem significados, mas enfrentam limites cuja desconsideração cria um descompasso entre a previsão constitucional (art.52, X) e o direito concretizado (abstrativização). 
Daí alguns doutrinadores chamarem a tese suscitada na Reclamação 4.335 de mutação inconstitucional, da forma como ali foi defendida.

São estas as abordagens do próximo capítulo, a hermenêutica constitucional e os limites a serem enfrentados pelos intérpretes do direito. 


\section{Capítulo 3}

\section{Hermenêutica constitucional e os sentidos mínimos do texto legal:}

\subsection{Mutação constitucional: a substituição de um texto por outro texto?}

Antes de adentrarmos no tema específico da mutação constitucional, necessário tecer alguns comentários acerca da função do intérprete do direito no exercício da sua atividade de interpretação das leis, mormente do texto constitucional.

O Professor Humberto Ávila nos ensina no seu livro intitulado “Teoria dos Princípios" que normas não são textos e nem o seu conjunto, mas significados construídos a partir da interpretação sistemática dos textos normativos. O que implica dizer que os dispositivos se constituem no objeto da interpretação e as normas, no seu resultado. Contudo, conforme nos alerta o citado professor, "o importante é que não existe correspondência entre norma e dispositivo, no sentido de que sempre que houver um dispositivo haverá uma norma (...)" (Ávila, 2012, p. 33). Isso significa que não há uma relação de reciprocidade entre as normas e o texto legal.

A partir dessas considerações, desvinculação entre o texto e os seus sentidos, pode-se concluir que a função da Ciência do Direito não se resume como mera descrição de significados preexistentes. A ideia de que o juiz é "a boca da lei", apenas reproduzindo a literalidade do texto, não faz mais sentido, já que a interpretação se caracteriza como ato de decisão que constitui a significação e os sentidos de um texto. Segundo Humberto Ávila: 
"Essas considerações levam ao entendimento de que a atividade do intérprete quer julgador, quer cientista - não consiste em meramente descrever o significado previamente existente dos dispositivos. Sua atividade consiste em constituir esses significados. Em razão disso, também não é plausível aceitar a ideia de que a aplicação do Direito envolve uma atividade de subsunção entre conceitos prontos antes mesmo do processo de aplicação" (Ávila, 2012, p. 35).

Contudo, essa função do intérprete, descrita por Ávila, de atribuir significados ao texto legal, não é ampla e irrestrita, o que poderia levar a decisões de cunho arbitrário, causando um quadro de insegurança jurídica. Isso porque existem os significados mínimos incorporados ao uso ordinário ou técnico da linguagem. Ao intérprete não é dada a liberdade de ignorar esses sentidos mínimos que preexistem ao processo particular de interpretação, pois decorrem de uma tradição, cultura ou costume já existentes, configurando o ponto de partida que não pode ser desprezado pelo intérprete.

O Ministro Eros Roberto Grau, ao defender a proposta de um novo texto normativo para o artigo $52, \mathrm{X}$ da $\mathrm{CF} / 88$, sob o argumento de que na mutação constitucional não se caminha de um texto a uma norma, mas de um texto a outro texto, que substitui o primeiro, simplesmente ignorou a tese sustentada por Humberto Ávila. O intérprete não pode desconsiderar os sentidos mínimos preexistentes no texto normativo ao interpretar, muito menos apresentar um novo texto, substituto do antecessor. Essa é a nossa percepção, obtida a partir da leitura dos ensinamentos do Professor Ávila no Capítulo 2 de seu livro.

Sustentar, como fez o ministro Eros Grau ao proferir seu voto na Rcl. 4.335-5, que a expressão "suspender a execução", constante do art. 52, X, deve ser substituída por "dar a publicidade à suspensão da execução" é menosprezar o texto normativo, que oferece limites à construção de sentidos e, ao mesmo tempo, serve como ponto de partida para a interpretação. Eros Grau foi além: não apenas ignorou o conteúdo do artigo 52, $\mathrm{X}, \mathrm{CF} / 88$, como propôs um novo conteúdo para o dispositivo, olvidando 
que o texto constitucional somente pode ser alterado mediante processo legislativo específico (art. 60, $\S 1^{\circ}, \mathrm{CF} / 88$ ).

A substituição de um texto por outro não é função do intérprete do direito, pois, se assim o fosse, do que valeria uma Constituição escrita quando delegado ao Judiciário o poder de alterá-la? Nesse caso, a mutação constitucional poderia significar, equivocadamente, a substituição do poder constituinte pelo Poder Judiciário.

O Supremo Tribunal Federal não pode criar uma nova competência para o Senado da República, pois disso cuidou o legislador constituinte originário no artigo 52 da atual Constituição da República, num rol taxativo de atribuições privativas. $\mathrm{O}$ entendimento manifestado pelos ministros Eros Grau e Gilmar Mendes na Reclamação 4.335-5 termina por criar uma nova atribuição para aquela casa legislativa, suprimindo-se, com isso, uma outra que, para eles, seria obsoleta.

Ainda que o conteúdo do artigo 52, X pareça destoar da realidade, é inaceitável uma tese que, sob a justificativa de estar-se interpretando a Constituição a fim de adequá-la ao devir social, venha a desprezar uma tradição presente desde 1934 e ratificada em 1988. E esse foi um dos argumentos utilizados pelo Min. Eros Grau para defender a suposta mutação do artigo 52, X, CF:

\footnotetext{
“4. O eminente Relator, jurista sensível à necessidade de adequação da Constituição ao devir social, em seu voto propõe que se a promova no que tange aos efeitos das decisões do Supremo no exercício do controle difuso. E o faz extraindo o seguinte sentido do texto do inciso $X$ do artigo 52 da Constituição, no quadro de uma autêntica mutação constitucional: ao Senado Federal está atribuída competência para dar publicidade à suspensão da execução de lei declarada inconstitucional, no todo ou em parte, por decisão definitiva do Supremo Tribunal Federal. A própria decisão do Supremo conteria força normativa bastante para suspender a execução da lei declarada inconstitucional" (Grau, 2007, p. 3).
}

O Ministro Eros Grau aduziu, ainda, em seu voto, que quando se está diante de uma mutação constitucional há sempre que se indagar se o texto 
dela resultante mantém-se adequado com a tradição do contexto. Tal entendimento foi assim manifestado:

\begin{abstract}
"Pois é certo que a unidade do contexto repousa em uma tradição que cumpre preservar. Recorro a JEAN-PIERRE VERNANT para dizer que o novo texto, para ganhar sentido, deve ser ligado e confrontado aos demais textos no todo que a Constituição é, compondo um mesmo espaço semântico. O que se há de indagar, neste ponto, é se o texto resultante da mutação mantém-se adequado à tradição [= à coerência] do contexto, reproduzindo-a, de modo a ele se amoldar com exatidão. A mutação não é uma degenerescência, senão uma manifestação de sanidade do ordenamento" (Grau, 2007, p. 12). (grifo nosso)
\end{abstract}

Porém, o novo texto apresentado pelo Ministro é totalmente dissociado da tradição, pois acaba com a participação do Senado da República no processo de controle da constitucionalidade, fazendo cair por terra o consolidado entendimento de que no controle difuso os efeitos são intersubjetivos, apenas admitindo-se sua extensão erga omnes com a edição da resolução suspensiva. Essa tradição sempre foi defendida tanto pela jurisprudência como pela doutrina, que reconhecem a importância do mecanismo da suspensão.

O ministro Joaquim Barbosa, ao enfrentar o tema, ressaltou que a proposta da mutação constitucional ocorre pela via interpretativa, havendo a partir dela tão-somente uma mudança no sentido da norma constitucional em questão. E essa mudança de sentido a qual se refere Joaquim Barbosa é feita pelo intérprete, a quem compete construir significados sem, contudo, menosprezar seus sentidos mínimos.

Assim manifestou-se o Min. Joaquim Barbosa:

“(...) Mas o que vislumbro com a proposta é que ocorrerá pura e simplesmente, pela via interpretativa, a mudança no sentido da norma constitucional em questão, hipótese essa que Canotilho, por exemplo, não elenca como modalidade idônea de mutação (Direito Constitucional, p.1102). Além disso, mesmo que se aceitasse a tese da mutação, entendo que seriam necessários dois fatores adicionais: o decurso de um espaço de tempo maior, para a constatação dessa mutação, e a conseqüiente e definitiva "désuetude" do dispositivo. Ora, em relação a esse último fator, impede, a meu juízo, esse reconhecimento um dado empírico altamente revelador: pesquisa rápida na base de dados do Senado Federal indica que desde 1988 aquela Alta Casa do Congresso suspendeu a execução de dispositivos de quase 100 normas declaradas inconstitucionais (sendo sete em 2006, Resoluções do SF de $n^{\circ} 10,11,12,13,14,15$ e 16; e uma já, neste ano, em 2007, resolução no 2)" (Barbosa, 2007, p. 4). (com os grifos) 
Por conseguinte, a mutação constitucional deve ser compreendida como uma ferramenta a ser utilizada pelo intérprete do direito para atribuir um novo significado ao texto normativo, construir normas, mas nunca para legislar, função essa que lhe é atípica. Assim, na mutação, caminha-se do texto normativo para a norma, e não de um texto para outro texto construído pelo próprio intérprete. Eros Grau chega a afirmar esse entendimento em partes do seu voto, entretanto, numa certa contradição, insiste que pela mutação o intérprete pode criar textos normativos.

Nos trechos abaixo transcritos o Ministro ressalta os limites a serem enfrentados pela mutação:

"7. Passo do texto do mito ao texto normativo para verificar que a este se amolda o quanto JEAN-PIERRE VERNANT afirmou a propósito do primeiro: $\boldsymbol{o}$ texto normativo obedece limitaç̃̃es coletivas bastante estritas nas variaç̃̃es às quais se presta ao ser transformado em norma; ainda quando operem o que chamamos de mudança de jurisprudência, os intérpretes autênticos não estão livres para modificá-lo, o texto normativo, à vontade, reescrevendo-o a seu belprazer; o intérprete inscreve-se na tradição do texto --- quer se amolde a ela com exatidão, quer se afaste dela em algum ponto, para atualizá-lo, o texto, é sustentado por ela, apóia-se nela e deve referir-se a ela, pelo menos implicitamente, se quiser que sua narrativa seja entendida pelo público" (Grau, 2007, p. 7); (grifo nosso)

"8. (...) Não se trata de afirmar que o intérprete autêntico tem legitimidade somente para repetir as palavras da lei, porém algo substancialmente diverso disso --- ele detém legitimidade para atuar plenamente no plano da dimensão normativa, para reproduzir o direito em sua dimensão normativa, fazendo-o, porém na língua dos textos normativos" (Grau, 2007, p. 8). (grifo nosso)

$(\ldots)$

"10. A mutação constitucional é transformação de sentido do enunciado da Constituição sem que o próprio texto seja alterado em sua redação, vale dizer, na sua dimensão constitucional textual" (Grau, 2007, p. 9). (grifo nosso)

Entretanto, após afirmar, no último trecho, que a mutação opera-se sem que o próprio texto seja alterado, assume posição diversa no mesmo tópico ao concluir que:

10. “(...) Há, então, mais do que interpretação, esta concebida como processo que opera a transformação de texto em norma. Na mutação constitucional caminhamos não de um texto a uma norma, porém de um texto a outro texto, que substitui o primeiro" (Grau, 2007, p. 9). (grifo nosso) 
Perceber-se, com isso, que as assertivas feitas por Eros Grau são um tanto conflitantes, pois ora afirma que a mutação se dá sem que o texto normativo seja alterado e ora defende que ela ocorre através da substituição de um texto por outro. Pergunta-se: o que de fato é a mutação constitucional para o ministro?

Manifestamos o entendimento, com base na leitura do livro do professor Humberto Ávila, de que a mutação somente pode ser utilizada como forma de reconstrução de sentidos. Contudo, conforme ressalva o autor:

"Isso não quer dizer, como já afirmado, que o intérprete é livre para fazer as conexões entre as normas e os fins a cuja realização elas servem. O ordenamento jurídico estabelece a realização de fins, a preservação de valores e a manutenção ou a busca de determinados bens jurídicos essenciais à realização daqueles fins e à preservação desses valores. O intérprete não pode desprezar esses pontos de partida" (Ávila, 2012, p. 37)

Nesse mesmo sentido, acerca do que é a mutação constitucional, as palavras de Nelson Nery Junior e Rosa Maria de Andrade Nery vão de encontro ao nosso ponto de vista:

\footnotetext{
"8. Mutação constitucional. Limites (I). Hodiernamente, a mutação constitucional deve ser entendida como adaptação interpretativa entre o texto constitucional e a realidade a ser operada principalmente pelos Tribunais Constitucionais. Contudo, a mutação possui limites, a fim de se evitar decisionismos e arbitrariedades, e ultrapassar esses limites implica violação do poder constituinte e da soberania popular (Barroso. Curso, p. 127). O texto constitucional, ou seja, o teor literal da $\mathrm{CF}$, demarca as fronteiras extremas das possíveis variantes de sentido, isto é, funcionalmente defensáveis e constitucionalmente admissíveis. Decisões que passam claramente por cima do teor literal da CF não são admissíveis (...)” (Nery Junior \& Nery, 2009, p. 420).
}

Ao defender a mutação constitucional do artigo $52, \mathrm{X}$ da $\mathrm{CF} / 88$, por meio da criação de um novo texto normativo, o Ministro Eros Roberto Grau desprezou a razão de ser do dispositivo, que decorre da necessária participação do Senado Federal no processo de controle da constitucionalidade como corolário do Estado Democrático de Direito e do princípio do Devido Processo Legal. Ademais, é ofender a Separação dos 
Poderes (art. $2^{\circ}$ da Constituição do Brasil), visto que teríamos o Poder Judiciário usurpando uma competência atribuída ao Poder Legislativo.

Logo, qualquer alteração do texto constitucional pela via interpretativa é contrária à própria Constituição, dando-se origem ao que alguns doutrinadores intitularam de "mutações inconstitucionais".

Assim sendo, a proposta de atribuir ao Senado a competência para dar publicidade às decisões do STF no controle difuso parece carecer de fundamentos jurídicos e hermenêuticos para sua concretização, eis que totalmente dissociada do contexto constitucional e da tradicional participação daquela casa legislativa no processo de controle de constitucionalidade incidenter tantum.

\subsection{Cabe ao Supremo Tribunal Federal corrigir a Constituição da República?}

O processo de controle da constitucionalidade encontra alicerce em 3 (três) princípios, quais sejam: (i) a supremacia da constituição significa que a Constituição está no topo da hierarquia das leis, sendo o fundamento de validade de todas as demais normas infraconstitucionais. Em suma, é a lei fundamental de um país e deve ser protegida para a própria manutenção das instituições do Estado Democrático de Direito; (ii) a rigidez constitucional revela a exigência de um processo legislativo mais complexo e rigoroso para que se altere o texto da Constituição do que aquele apto a gerar normas infraconstitucionais. A rigidez constitucional encontra seu fundamento no artigo 60 da CRFB/88; (iii) por fim, a presunção de constitucionalidade estabelece que aquelas normas que buscaram fundamento de validade na Lei Maior gozam de uma presunção relativa de validade, ou seja, que respeitaram a Constituição tanto nos seus aspectos formal como material.

As únicas normas que gozam de presunção absoluta de validade e por isso não podem ser objeto de controle da constitucionalidade são as 
constitucionais originárias, em outras palavras, nascidas a partir do poder constituinte originário.

A partir dessa síntese pode-se concluir que controlar a constitucionalidade das leis consiste na verificação de sua compatibilidade material e formal diante do texto constitucional, já que esse serve como parâmetro de validade para aquelas.

Ao Supremo Tribunal Federal foi atribuída a função de guardião da Constituição da República, o que permite dizer que a ela está subordinado, devendo-lhe zelo e obediência.

Pois bem, o STF, como guardião da Constituição do Brasil, ao exercer o controle de constitucionalidade de leis ou atos normativos, seja pela via de ação direta como pela via incidental, deverá analisar sua compatibilidade com a lei maior nos seus aspectos materiais e formais. No exercício dessa atividade, a Corte obedecerá a todos os comandos constitucionais previstos que visem a dar concretude a esse controle, sendo vedado, ao órgão de cúpula, subverter esse procedimento a partir de uma tese que descarta um dispositivo constitucional, sob o argumento de não ser ele mais compatível com a realidade jurídica.

Ao pretender que o artigo 52, $\mathrm{X}$ da $\mathrm{CF}$ passasse por uma reforma com a alteração do seu conteúdo substancial, quis o STF, na verdade, corrigir a Carta Política, fazendo-se substituir pelo Poder Legislativo único detentor do poder constituinte derivado reformador.

Somente com uma reforma constitucional legítima, através da chamada Emenda Constitucional, é possível acabar com a competência prevista no artigo 52, X da Constituição da República. E ainda que essa reforma um dia venha a acontecer, não será possível, mesmo assim, falar-se em efeitos vinculantes de toda e qualquer decisão proferida pela Corte Constitucional, eis que, conforme já ressaltado, a Carta Magna somente 
prevê aquelas espécies de efeitos em duas situações específicas: (i) no exercício do controle concentrado de constitucionalidade; ou (ii) com a edição de súmula vinculante.

Como dito no tópico anterior, a interpretação constitucional é limitada pelo próprio texto normativo, dessa forma quanto mais preciso for o texto, menor será a atividade interpretativa. Assim sendo, a referida mutação constitucional aparenta certa ilegitimidade, pois ultrapassa os limites a que está adstrito o intérprete do direito, uma vez que o art. 52, X da Constituição é um dispositivo objetivo e claro. Portanto, não se mostra razoável uma interpretação tão extensiva quanto a que foi sustentada pelos Ministros Gilmar Mendes e Eros Grau na reclamação 4.335/AC.

Ademais, os princípios da força normativa da Constituição e da máxima efetividade das suas normas vedam a possibilidade de que se supra ou diminua a finalidade do texto constitucional. São princípios que buscam o máximo de efeitos jurídicos que uma norma possa produzir.

Assim, como o artigo 52, X, da Constituição - que dispõe expressamente sobre a competência privativa do Senado em suspender a execução, no todo ou em parte, de lei declarada inconstitucional por decisão definitiva do STF - pode ter seu significado transformado, determinando uma nova competência privativa ao Senado que consiste em dar publicidade à suspensão da execução realizada pelo próprio STF. Ou seja, passa-se de uma função ativa, como componente de um ato complexo, para uma passiva, como simples dever de fazer publicar as decisões do STF.

\subsection{A tese da mutação como perigoso precedente:}

A tese da mutação constitucional suscitada no julgamento da Reclamação 4.335-5 caracteriza-se por sua peculiaridade, pois com base nela os ministros Gilmar Mendes e Eros Grau pretenderam acabar com uma tradição presente no ordenamento jurídico desde 1934. O poder constituinte originário àquela época estabeleceu a competência privativa do Senado 
Federal para suspender a execução, no todo ou em parte, de qualquer lei ou ato, deliberação ou regulamento, quando declarados inconstitucionais pelo Poder Judiciário. Essa era a redação do artigo 91, IV, da Constituição de 1934. Mecanismo mantido pela atual Carta Política e que se encontra presente no artigo 52, $\mathrm{X}$.

Por mais que essa atuação do Senado da República possa ter sido mitigada, tendo em vista a prioridade dada ao controle concentrado de constitucionalidade, sua importância não foi abandonada pela jurisprudência e, muito menos, pela doutrina constitucional, as quais sempre vislumbraram no papel do Senado uma importante participação política e democrática no processo de controle da constitucionalidade.

O doutrinador Teori Albino Zavascki em seu livro "Eficácia das Sentenças na Jurisdição Constitucional” traz importante fato histórico no que diz respeito à razão de ser do instituto da suspensão:

"O instituto da suspensão foi introduzido pela Carta de 1934, por iniciativa de Prado Kelly, que, mais tarde, como Ministro do Supremo, explicou a razão da proposta: 'A jurisprudência pacífica do STF negava a extensão a outros interessados dos efeitos das suas decisões. O julgado estava, como é de communis opinio, adstrito à questão focalizada pela Corte. Só em habeas corpus (impetrado o primeiro deles pelo Conselheiro Rui Barbosa, para assegurar a liberdade de reunião em praça pública) se admitiu a extensão da medida erga omnes. Então, acudia naturalmente aos estudiosos dos fatos jurídicos a conveniência de instituirse meio adequado à pronta suspensão dos efeitos, para terceiros, das leis e regulamentos declarados inconstitucionais pela Suprema Corte. Foi uma inspiração de ordem prática. Mas a fórmula adotada pela Constituinte de 1934 obedecia, ainda, a razões de ordem técnica. O regulamento, a lei, podiam provir da União, dos Estados-Membros ou dos Municípios. Se se aguardasse a revogação, para alcance geral, de norma eivada de inconstitucionalidade, escaparia ao Legislador Federal o ensejo, em muitos casos, de corrigir os defeitos estranhos à sua competência, como por exemplo, os da órbita estadual ou municipal'" (Zavascki, 2012, p. 31).

Com base nesse apanhado histórico nota-se que a preocupação do legislador constituinte já em 1934 foi a de atribuir à decisão proferida no caso concreto efeitos ultra partes, protegendo terceiros que não estavam $a$ priori abarcados pela decisão de inconstitucionalidade. 
Essa foi uma escolha do poder constituinte originário de 1988 em manter o sistema de controle de constitucionalidade híbrido no país, com a manutenção participação do Senado no controle difuso.

Ademais, trata-se de um ato político discricionário, podendo o Senado tomar uma de duas atitudes: (a) concordar com a decisão do STF e, por consequência, emitir resolução suspendendo a execução, em todo território nacional, da lei declarada inconstitucional pelo Tribunal; ou (b) não concordar com o STF e não emitir a resolução de que trata o artigo 52, $\mathrm{X}, \mathrm{CF}$.

O STF, ao avocar uma competência privativa do Senado da República, determinada pela Constituição da República, demonstra um flagrante desrespeito ao princípio da separação de Poderes, além de pôr em risco o sistema de freios e contrapesos. E esta tentativa de atribuir efeitos vinculantes aos precedentes do Tribunal, independentemente da edição de resolução suspensiva, é justificada com base na teoria da mutação constitucional.

A mutação constitucional, segundo Nelson Nery Junior, é procedimento natural, que se verifica em razão da evolução da sociedade, de modo a exigir nova interpretação do pacto constitucional, que não se altera com a mutação, o que significa a impossibilidade de decidir-se contra o texto expresso da Constituição, utilizando-se do instituto da mutação.

Caminhar no sentido da mutação constitucional, da forma como sustentada na Reclamação 4.335, é atribuir ao órgão de cúpula do Poder Judiciário liberdade para, no exercício da interpretação do texto constitucional, desconsiderar seus sentidos mínimos e com isso possibilitar que em futuros casos o mesmo entendimento venha a ser adotado.

Em suma, trata-se de um perigoso precedente, pois autoriza que a Corte crie o direito, desprezando normas claras e objetivas que foram 
criadas pelo constituinte originário. A construção de sentidos pelo intérprete deve ser feita à luz texto normativo, sendo-lhe vedado passar por cima do dispositivo legal que, conforme já afirmado, consiste no objeto da interpretação. Ademais, segundo Humberto Ávila:

"(...) o intérprete deve interpretar os dispositivos constitucionais de modo a explicitar suas versões de significado de acordo com os fins $e$ os valores entremostrados na linguagem constitucional" (Ávila, 2012, p. 38). (grifo nosso)

A tese da abstrativização do controle difuso busca, de certa forma, restringir, ainda mais, que recursos extraordinários cheguem ao Tribunal Constitucional, visto que qualquer decisão passaria a ter efeitos vinculantes. Todavia, a ideia de efeitos vinculantes dos julgados autorizaria, por outro lado, a escolha da Reclamação Constitucional sempre que um juiz ou Tribunal manifestasse entendimento diverso. Isso faria com que se reduzisse o número de REs interpostos, porém aumentaria o número de reclamações, o que, na prática, não acabaria com o excesso de demanda perante a Corte.

$\mathrm{Na}$ hipótese de surgirem interpretações divergentes acerca de uma mesma matéria constitucional, o legislador constituinte, prevendo desde já tal possibilidade, instituiu a Ação Declaratória de Constitucionalidade a fim de acabar com ao quadro de insegurança jurídica decorrente de controvérsia judicial.

Sustentar a eficácia erga omnes de qualquer decisão proferida pelo STF acerca de matéria constitucional no exercício do controle difuso faz com que a ADC perca a sua razão de ser, porque, dessa forma, não haverá mais controvérsia judicial e assim o requisito exigido pela lei 9.868/99 em seu artigo 14, inciso III não será preenchido.

Assim é que não se mostra razoável afirmar que as decisões de constitucionalidade e inconstitucionalidade oriundas da Corte Suprema possuem efeitos vinculantes contra todos, pois existe no ordenamento jurídico um mecanismo, cuja finalidade é justamente pôr fim a 
controvérsias judiciais relevantes. Se aquela premissa fosse verdadeira, nada justificaria a criação da Ação Direta de Constitucionalidade.

As controvérsias judiciais que, por ventura, venham a surgir são decorrentes da liberdade dos órgãos do Poder Judiciário de interpretarem a Constituição. Essas divergências jurisprudenciais representam um debate saudável sobre a matéria constitucional. Ainda que estas interpretações heterogêneas possam causar certa instabilidade jurídica e, por conseguinte, uma multiplicação de recursos constitucionais perante a Corte Suprema, não se mostra democrática a ideia de monopolizar essa atividade. Seria uma afronta à autonomia do Judiciário a vinculação de todos os seus órgãos aos precedentes da Corte.

Enfim, mostra-se mais coerente com o Estado Democrático de Direito (art. $1^{\circ}$, caput, CRFB/88) a possibilidade de juízes e Tribunais interpretarem livremente o texto constitucional, buscando subsídios ou não nas decisões da Corte, exceto naquelas hipóteses de vinculação prevista pela própria Constituição Brasileira. 


\section{Conclusão}

Conforme narrado nos capítulos acima, vimos que a tese da abstrativização do controle difuso de constitucionalidade ganhou destaque no cenário jurídico a partir da Reclamação Constitucional 4.335-5/AC, em que se debateu o suposto caráter vinculante das decisões proferidas pelo Supremo Tribunal Federal no caso concreto. A princípio essa decisão incidental somente produz efeitos retroativos inter partes, deixando de beneficiar aqueles que não figuraram na relação processual, somente admitindo-se efeitos erga omnes a partir de um ato político discricionário emanado do Senado da República, que consiste na edição de uma resolução suspensiva (artigo 52, X, CF). Porém, o Ministro Gilmar Mendes, relator da Rcl. 4.335, ao proferir seu voto, manifestou-se pela procedência do pedido formulado pela Reclamante (DPU), alegando que qualquer decisão proferida pela Corte num caso concreto deveria, sim, ser de observância obrigatória. O Ministro Eros Grau também defendeu essa tese, acrescentando, ainda, a mutação constitucional sofrida pelo artigo 52, X da Constituição da República. Para ambos os Ministros a atuação do Senado no processo de controle da constitucionalidade é prescindível, tornando a redação do citado dispositivo anacrônica diante da atual conjuntura do ordenamento jurídico.

Contudo, demonstramos que a participação daquela casa legislativa no processo de controle da constitucionalidade difuso foi uma escolha do legislador constituinte originário - participação essa, presente no constitucionalismo brasileiro desde 1934, apenas sendo suprimida quando da Carta Política de 37. Também buscamos destacar que o Brasil adota um sistema misto de controle da constitucionalidade, característica essa peculiar nossa. Além disso, a importância do Senado Federal está no fato de essa casa legislativa realizar uma fiscalização da decisão que declarou inconstitucional um diploma legal. Caso o STF tenha proferido uma decisão violadora de algum princípio constitucional, v.g., do devido processo legal, 
ou mesmo que inobservou a cláusula de reserva de plenário, não poderá a Câmara Alta editar a competente resolução suspensiva. Outro ponto relevante que procuramos explanar foi o fato de que uma decisão casuística, proferida por maioria apertada, não evidencia um entendimento homogêneo acerca da matéria constitucional. O que levaria o Senado Federal, nessa hipótese, a omitir-se do seu papel, sob a justificativa daquela decisão ser nociva para os cidadãos brasileiros. No entanto, sabemos, que uma decisão no controle concentrado por 6 (seis) votos a 5 (cinco) também é capaz de "derrubar" um diploma legal, independentemente de ser um entendimento divergente, não amadurecido.

Dessa forma, sustentar, como o fizeram os Ministros Gilmar Mendes e Eros Grau, que ao Senado da República compete dar publicidade às decisões do STF, que tenham declarado a inconstitucionalidade de lei ou ato normativo, é passar por cima da literalidade do artigo 52, X da CF/88. Ademais, procuramos destacar que a tese da abstrativização faz cair por terra a própria diferença entre os efeitos do controle concentrado e do controle difuso de constitucionalidade, eis que os equipara.

Outro ponto importante, por nós sustentado, é que a abstrativização faz com que a Súmula Vinculante perca sua razão de ser, pois uma decisão no controle difuso por 6 (seis) votos a 5 (cinco) passará a ter a mesma eficácia que uma proferida por 8 (oito) a 3 (três), que é o quorum mínimo exigido para sua aprovação, além ter que obedecer a outro importante requisito, qual seja, a exigência de reiteradas decisões. Assim, uma súmula vinculante mostra-se mais adequada, pois se exige não apenas um quorum mais seguro para a sua edição como também a necessidade de reiteradas decisões. Justamente por existir essa ferramenta trazida pela Emenda Constitucional n. 45/04 é que não poderiam os Ministros da Corte defenderem a possibilidade de efeitos vinculantes para qualquer espécie de decisão proferida no bojo de um processo subjetivo. 
Enfatizamos que a tese da abstrativização também fez com que outro mecanismo previsto na Constituição Federal ficasse sem sentido: a Ação Declaratória de Constitucionalidade (ADC). O legislador constituinte reformador (EC n. 3/93) previu que na hipótese de haver divergência jurisprudencial relevante, decorrente de interpretações judiciais conflitantes, fosse esta insegurança sanada através da ADC. A finalidade dessa medida é muito clara: afastar a incerteza jurídica e estabelecer uma orientação homogênea na matéria. Porém, se uma decisão do STF passar a ter eficácia vinculante para todos os órgãos do Poder Judiciário, depreende-se que, apesar de pôr fim ao quadro de insegurança jurídica, mitigará a autonomia daqueles órgãos na interpretação do texto constitucional e, por conseguinte, fará a ação declaratória perder sua ratio.

Por existirem alternativas ao procedimento do artigo 52, $\mathrm{X}$ da $\mathrm{CF}$, é que o STF não poderia sustentar o fim da participação do Senado Federal no controle de constitucionalidade difuso, suprimindo-se, com isso, um dispositivo constitucional.

Alertamos para o perigoso precedente que poderá se tornar a Reclamação Constitucional 4.335-5, mormente pela forma como foi defendida a mutação constitucional pelo Min. Eros Roberto Grau. A mutação, sob a ótica do Ministro, permite que o intérprete não apenas mude o significado do texto normativo, mas autoriza-o ir além, podendo substituir uma previsão constitucional por outra. Discordamos desse conceito de mutação constitucional, pois o intérprete do direito não pode fazer-se substituir pelo legislador reformador ignorando o texto constitucional, e desprezando os limites a que está adstrito. Temos consciência da importância do Poder Judiciário para a construção do direito diante das peculiaridades do caso concreto, porém essa atividade não pode ignorar os sentidos mínimos preexistentes ao processo de interpretação. 
Em suma, acreditamos faltar à tese da abstrativização fundamento jurídico que justifique sua concretização, seja porque não há dispositivos constitucionais e processuais que a autorizem, seja porque já há no ordenamento jurídico um mecanismo que alcança os mesmo efeitos pretendidos por ela. Trata-se da súmula vinculante, único instrumento adequado para vincular os demais órgãos do Poder Judiciário e que transmite maior segurança jurídica. A liberdade do Poder Judiciário não pode ser tolhida por uma tese que busca concentrar a interpretação do texto constitucional a um único órgão. $\mathrm{O}$ controle difuso representa, na verdade, a concretização do princípio democrático, pois através dele qualquer juiz ou Tribunal possui a prerrogativa de analisar a compatibilidade de leis e atos normativos com a Constituição da República. 


\section{Bibliografia}

ÁVILA, Humberto. Teoria dos Princípios: da definição à aplicação dos princípios jurídicos. 13ª edição. São Paulo: Malheiros, 2012. 215 p.

BARROSO, Luís Roberto. $O$ controle de constitucionalidade no direito brasileiro: exposição sistemática da doutrina e análise crítica da jurisprudência. $6^{\text {a }}$ edição, revista e atualizada. São Paulo: Saraiva, 2012. $452 \mathrm{p}$.

DOURADO, Maristela Seixas. O papel do Senado Federal no controle de constitucionalidade. Brasília - DF. 2008. 83 p. Monografia (Pós-Graduação lato sensu em Direito Legislativo) - Universidade do Legislativo Brasileiro. Disponível/em<http://www2.senado.gov.br/bdsf/bitstream/id/162780/1/Mo nografia\%20Completa.pdf> Acesso em 6 de maio 2012.

JÚNIOR, Humberto Theodoro. Curso de direito processual civil, vol. 1. 53 edição, revista e atualizada. Rio de Janeiro: Forense, 2012. 822 p.

Código de Processo Civil anotado. $16^{\mathrm{a}}$ edição, revista, atualizada e ampliada. Rio de Janeiro: Forense, 2012. 2.012 p.

LEITE, Fábio Carvalho. A Cláusula de Reserva de Plenário segundo os Tribunais de Justiça. Direitos Fundamentais \& Justiça: Revista do Programa de Pós-Graduação, Mestrado e Doutorado em Direito da PUCRS. Rio Grande do Sul, n. 15, p. 210 - 229, abr./jun. 2011.

ADIN E ADC, e a ambivalência possível: uma proposta. Revista de Direito do Estado (RDE), vol. 10. Rio de Janeiro: Ed. Renovar, 2008. p. $67-99$.

LENZA, Pedro. Direito Constitucional Esquematizado. 14 ${ }^{\mathrm{a}}$ edição, revista, atualizada e ampliada. São Paulo: Saraiva, 2010. 926 p. 
MARTINS, Flavia Bahia. Direito Constitucional. $2^{\mathrm{a}}$ edição, revista, ampliada e atualizada. Rio de Janeiro: Impetus, 2011. 582 p.

MENDES, Gilmar Ferreira; COELHO, Inocêncio Mártires; BRANCO, Paulo Gustavo Gonet. Curso de Direito Constitucional. $4^{\mathrm{a}}$ edição, revista e atualizada. São Paulo: Saraiva, 2009. 1.486 p.

MENDES, Gilmar Ferreira. Estado de Direito e Jurisdição Constitucional: 2002 - 2010. São Paulo: Saraiva, 2011. 1.451 p.

O papel do Senado Federal no controle de constitucionalidade: um caso clássico de mutação constitucional. Disponível em < http://www2.senado.gov.br/bdsf/bitstream/id/953/4/R162-12.pdf > Acesso em 14 de abr. 2012.

NERY JUNIOR, Nelson; NERY, Rosa Maria de Andrade. Constituição Federal Comentada e Legislação Constitucional. $2^{\mathrm{a}}$ edição, revista, ampliada e atualizada. São Paulo: Revista dos Tribunais, 2009. 1.529 p.

NERY JUNIOR, Nelson. O Senado Federal e o controle concreto de constitucionalidade de leis e de atos Normativos: Separação de poderes, Poder Legislativo e interpretação da $C F \quad 52 \quad X$. Disponível em 〈http://www2.senado.gov.br/bdsf/bitstream/id/198654/1/000849755.pdf > Acesso em 12 de maio 2012.

SILVA, José Afonso da. Curso de Direito Constitucional Positivo. $31^{\mathrm{a}}$ edição, revista e atualizada. São Paulo: Malheiros Editores, 2008. 926 p.

STRECK, Lênio Luiz. A Nova Perspectiva do Supremo Tribunal Federal sobre o Controle Difuso: Mutação constitucional e Limites da Legitimidade da Jurisdição $\quad$ Constitucional. $\quad$ Disponível em <http://www.leniostreck.com.br/site/wp-content/uploads/2011/10/4.pdf $>$ Acesso em 28 de abr. 2012.

STF, Rcl. n 4335-5/AC, Rel. Min. Gilmar Mendes, Brasília, 19 abr. 2007. 
STF, ADI no $3.929 \mathrm{MC} / \mathrm{DF}$ - Distrito Federal, Rel. ${ }^{a}$ Min. ${ }^{a}$ Ellen Gracie, Brasília, 29 ago. 2007.

STF, Rcl. no $10.793-S P$, Rel. ${ }^{a}$ Min. ${ }^{a}$ Ellen Gracie, Brasília, 13 abr. 2011.

ZAVASCKI, Teori Albino. Eficácia das Sentenças na Jurisdição Constitucional. $2^{\mathrm{a}}$ edição, revista, atualizada e ampliada. São Paulo: Revista dos Tribunais, 2012. 204 p. 